\title{
An Archaeological Investigation of Comanche Lookout Park, Northeast Bexar County, Texas
}

David L. Nickels

Follow this and additional works at: https://scholarworks.sfasu.edu/ita

Part of the American Material Culture Commons, Archaeological Anthropology Commons, Environmental Studies Commons, Other American Studies Commons, Other Arts and Humanities Commons, Other History of Art, Architecture, and Archaeology Commons, and the United States History Commons

Tell us how this article helped you.

This Article is brought to you for free and open access by the Center for Regional Heritage Research at SFA ScholarWorks. It has been accepted for inclusion in Index of Texas Archaeology: Open Access Gray Literature from the Lone Star State by an authorized editor of SFA ScholarWorks. For more information, please contact cdsscholarworks@sfasu.edu. 


\section{An Archaeological Investigation of Comanche Lookout Park, Northeast Bexar County, Texas}

\section{Creative Commons License}

\section{(c) (1) \&}

This work is licensed under a Creative Commons Attribution-NonCommercial 4.0 International License 


\section{An Archaeological Investigation of}

\section{Comanche Lookout Park,}

Northeast Bexar County, Texas

David L. Nickels

Center for Archaeological Research * The University of Texas at San Antonio - Archaeological Survey Report, No. $275 \div 1998$ 



\title{
An Archaeological Investigation of Comanche Lookout Park, Northeast Bexar County, Texas
}

\author{
David L. Nickels
}

Robert J. Hard and C. Britt Bousman

Principal Investigators

Ccopyright 1998

Center for Archaeological Research

The University of Texas at San Antonio

Archaeological Survey Report, No. 275 
The following information is provided in accordance with the General Rules of Practice and Procedure, Chapter 41.11 (Investigative Reports), Texas Antiquities Committee:

1. Type of investigation: Survey and limited testing

2. Project name: Comanche Lookout Park

3. County: Bexar

4. Principal investigators: Robert J. Hard and C. Britt Bousman

5. Name and location of sponsoring agency: City of San Antonio Parks and Recreation Department, P.O. Box 839966, San Antonio, Texas 78283-3966

6. Texas Antiquities Permit No.:1876

7. Published by the Center for Archaeological Research, The University of Texas at San Antonio, 6900 N. Loop 1604 W., San Antonio, Texas 78249-0658, 1998

A list of publications offered by the Center for Archaeological Research is available. Call (210) 458-4378; write to the Center for Archaeological Research, The University of Texas at San Antonio, 6900 N. Loop 1604 W., San Antonio, Texas 78249-0658; e-mail to car@lonestar.utsa.edu; or visit CAR's web site at http://www.csbs.utsa.edu/research/car/index.htm. 


\begin{abstract}
During the week of September 22 through 26, 1997, staff archaeologists from the Center for Archaeological Research (CAR) of The Unviersity of Texas at San Antonio conducted a 100-percent-pedestrian survey and limited shovel testing at Comanche Lookout Park in northeastern Bexar County, Texas (Figure 1). The archaeological investigation was conducted at the request of the city of San Antonio Parks and Recreation Department as part of an overall development plan for the 96-acre parcel (Figure 2). The purpose of the survey was to identify archaeological sites visible on the surface as well as areas where sites are potentially buried. CAR archaeologists revisited and recorded three artifact scatters initially documented in 1992 by members of the Southern Texas Archaeological Association and other volunteers led by H. Ray Smith, an Archaeological Steward with the Office of the State Archaeologist. As a result of CAR's survey, the three scatters were included within the boundaries of what was determined to be a large quarry and lithic reduction site surrounding the hill, with an open campsite area on top. In addition, CAR archaeologists discovered and recorded two smaller sites near the base of the hill (Figure 2). A plan of avoidance is recommended for two of the three archaeological sites; however, if the proposed construction plan can not be altered to accommodate both the needs of the city and the recommendation of avoidance, then further testing is recommended.
\end{abstract}




\section{Contents}

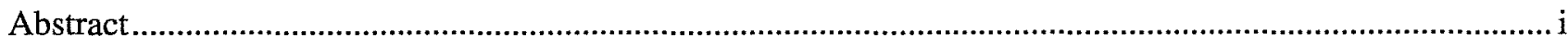

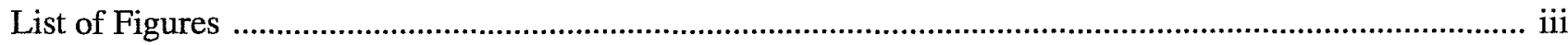

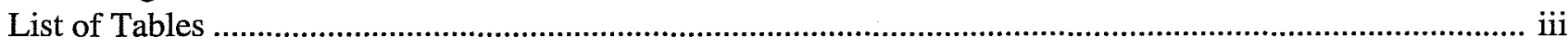

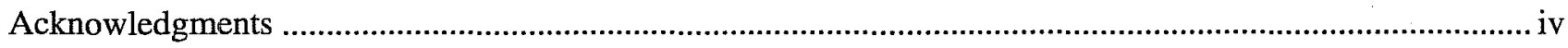

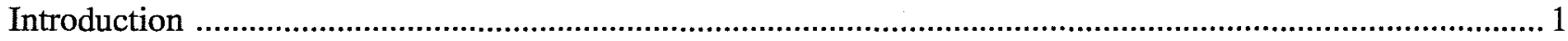

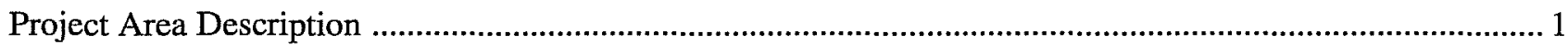

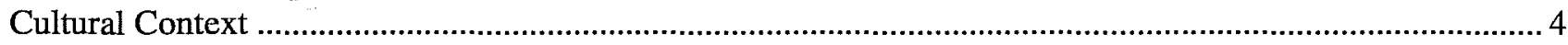

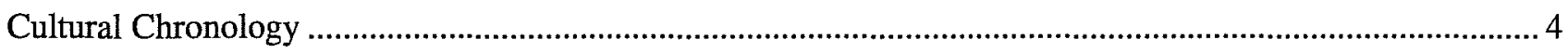

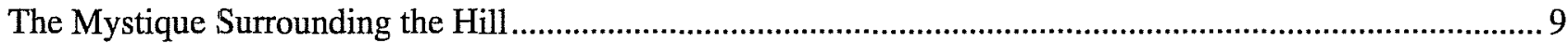

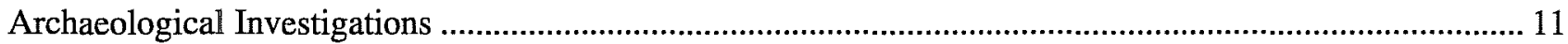

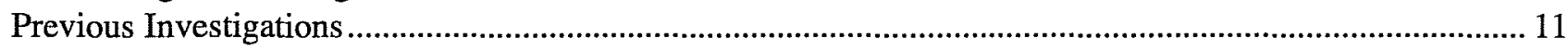

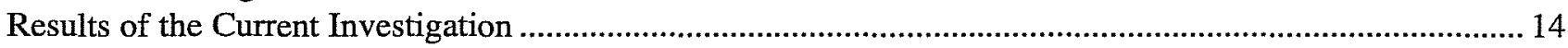

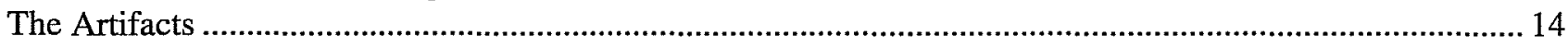

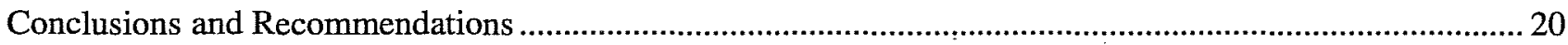

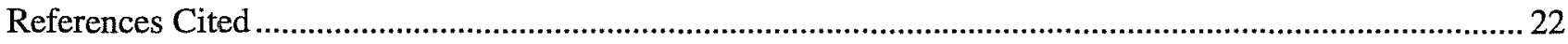

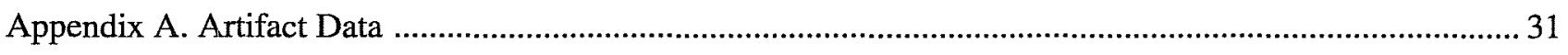




\section{Figures}

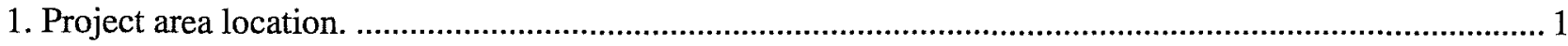

2. City of San Antonio Parks and Recreation Department development plan superimposed

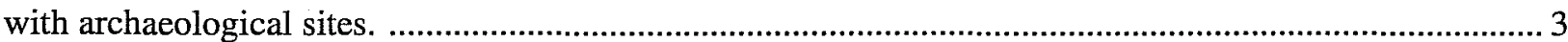

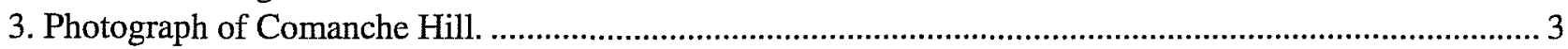

4. Photograph of the tower constructed by Colonel Coppock........................................................................ 11

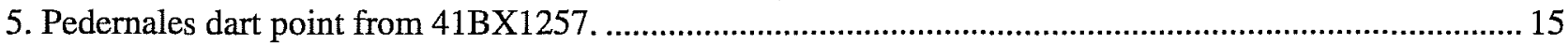

6. Early Archaic Guadalupe biface from 41BX1257. left: dorsal view; right: lateral view. ........................... 14

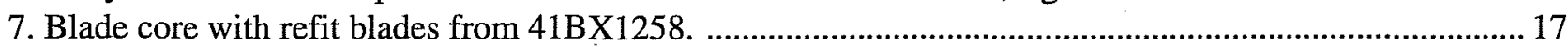

8. Single blade recovered from 41BX1258. left: dorsal view; right: ventral view ...................................... 16

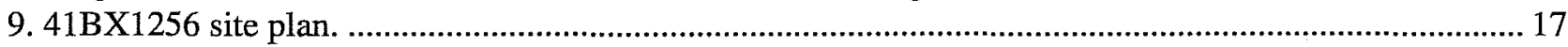

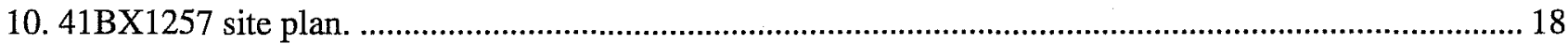

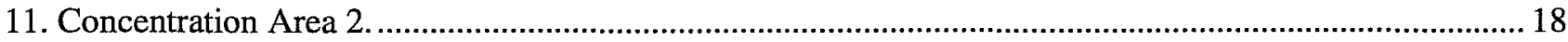

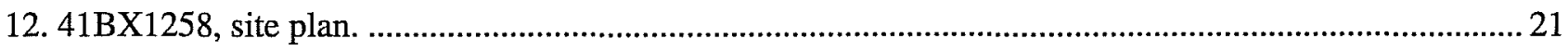

\section{Tables}

1. Central and South Texas Chronologies ................................................................................................. 


\section{Acknowledgments}

The author would like to thank landscape architect and project officer Mr. Paul B. Barwick from the City of San Antonio Parks and Recreation Department for his support as the park design and project services officer. The project could not have been completed without the able fieldwork of UTSA staff archaeologists Diane Cargill, Christopher Cooley, Christopher Horrell, Ruth Mathews, Preston McWhorter, and Ricky Robinson who were there despite the adverse weather conditions. Bruce Moses contributed his expertise in total data station mapping and artifact illustration for this report, and as always, Marcie Renner's technical support as editor is greatly appreciated. A special thanks to Texas State Archaeological Steward, H. Ray Smith who freely provided extremely valuable maps, documents and general information about the archaeological sites within the park. A special thanks also to Dr. Steve Tomka, for his advice and support during the lithic analysis. Dr. Robert J. Hard and Dr. C. Britt Bousman are thanked for providing professional advice and guidance throughout the project.

Finally, a sincere thank you to Celia Prehn, spokesperson for the Save Comanche Lookout Group. Without her persistence, futuristic vision, and community organizational abilities, there would probably not be a Comanche Lookout Park. 


\section{Introduction}

The fourth highest point in Bexar County (USGS), and the highest point in the northeastern part of the county, is known as Comanche Hill or Comanche Lookout. In August 1997, Parks Design and Services Project Coordinator Paul B. Barwick, acting on behalf of the city of San Antonio Parks and Recreation Department, contracted with the Center for Archaeological Research (CAR) of The University of Texas at San Antonio to conduct an archaeological site assessment via a pedestrian survey and limited shovel testing of the 96-acre Comanche Lookout Park. The city asked for the assessment as part of an overall development plan for the park. Comanche Lookout Park is located along Judson and Nacogdoches roads in northeast Bexar County (Figure 1). Planned development of the 96 acres of land as a new city park included construction of paved parking areas, an emergency access road, picnic and restroom facilities, a pedestrian and bicycle trail system, a stone patio within the foundation of the Coppock house, and restoration of the Coppock stone tower (Figure 2). CAR conducted the project from September 22-26, 1997, under Texas Antiquities Permit number 1876, issued by the Texas Historical Commission. The survey documented three archaeological sites, one of which would be impacted by construction (Figure 2).

\section{Project Area Description}

Comanche Lookout lies at the southeastern edge of the Edwards Plateau, in central Texas's "Hill Country," so named for its rugged, stream-eroded topography. The 96-acre parcel is dominated by Comanche Hill (Figure 3) which reaches an elevation of $1,340 \mathrm{ft}$, and prominently rises above the surrounding rolling terrain which makes up the western edge of the Blackland Prairie. The environmental zone can be classified as upland,

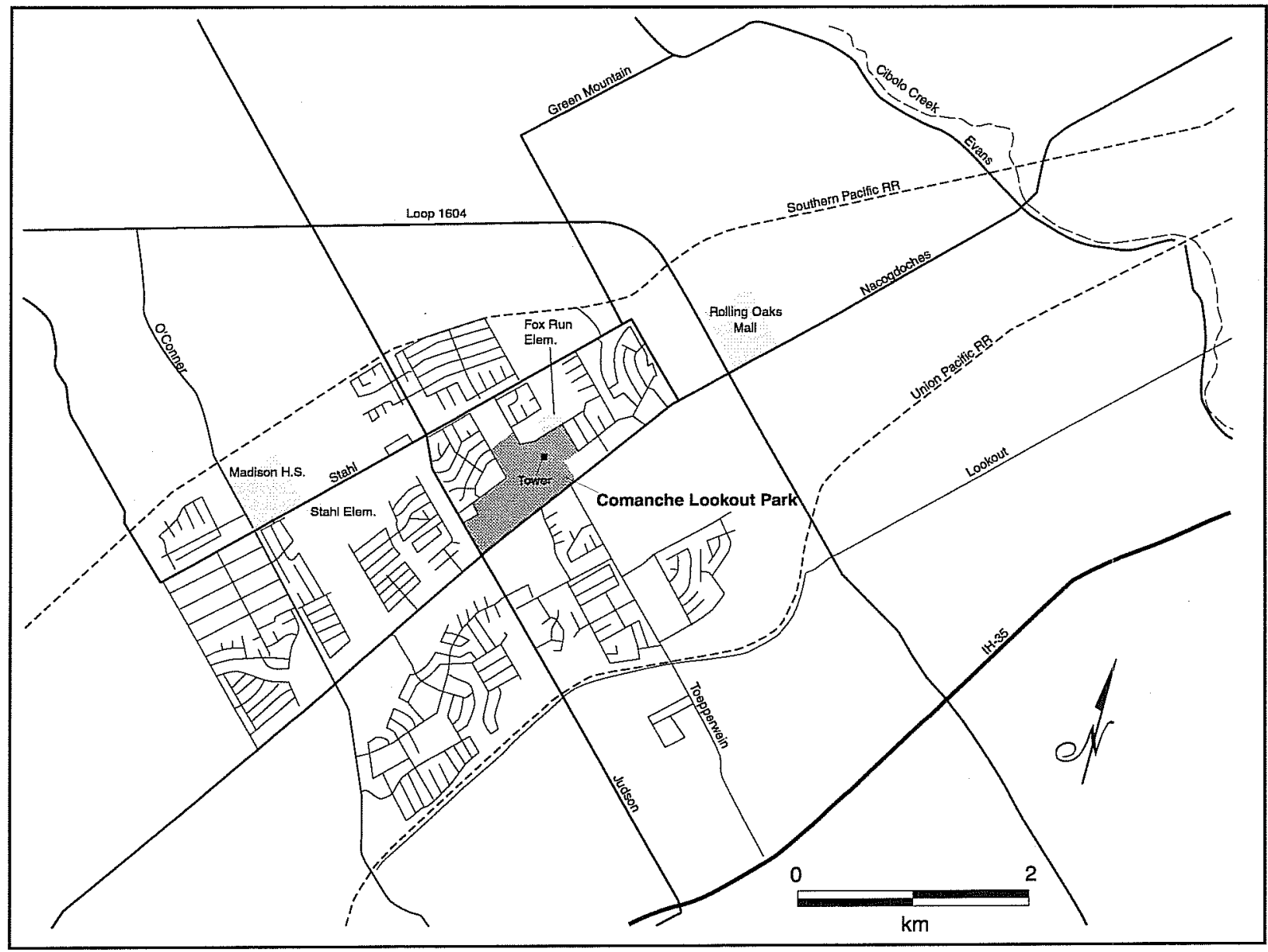

Figure 1. Project area location. 
This page has been

redacted because it

contains restricted

information. 


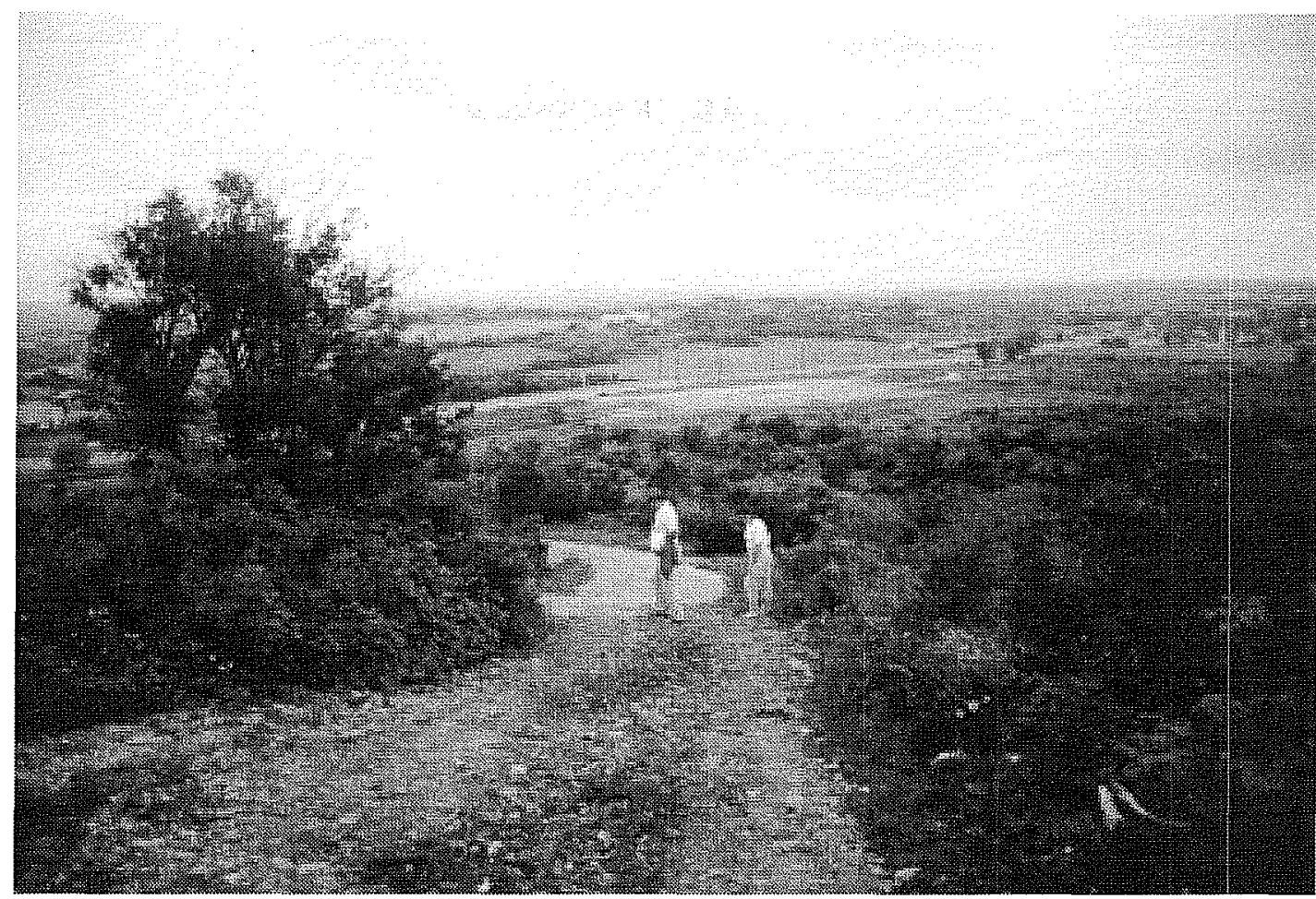

Figure 3. Photograph of Comanche Hill.

with two intermittent drainages. The annual average rainfall is about 28 inches, with 245 growing-season days per year (Taylor et al. 1991:118-121).

The hill is composed of Pecan Gap Chalk (Barnes 1993), overlain with Tarrant (Tb) soil. The latter is normally present on broad ridge tops and the surrounding slopes. Because of their location, Tarrant soils are often shallow and subject to frequent erosion, making the vegetational cover suitable for minimum grazing. On the lower southern slope are soils of the Brackett-Austin complex (BsC), a shallow to moderately deep clay loam which makes good pasture land. Austin silty clay (AuC), also good for pasturing cattle, is present along both sides of the southern intermittent drainage slopes and Trinity Frio (Tf) soils cover the immediate slopes of the drainage. Trinity Frio soils are commonly found along smaller drainages and are best suited for grazing (Taylor et al. 1991:10, $12,31,33)$.

The nearest extant water is Cibolo Creek, although in the immediate area of Comanche Hill it flows only when flooded. The creek originates approximately $16 \mathrm{~km}$ west of Boerne, in Kendall County, from springs flowing out of Edwards Limestone hills. A few kilometers downstream the creek disappears from the surface as it drops into the Glen Rose formation and Edwards Underground Aquifier (Gerstle et al. 1978:31). The creek is subject to flash flooding during locally heavy thunderstorms.

Lithic resources in the form of Edwards formation chert were observed in abundance around the hill, and are available in the cutbanks and bottom of Cibolo Creek. These resources and the documentation of a prehistoric quarry and lithic workshop (McGraw and Valdez 1978) to the west suggest that raw materials for making stone tools were readily available.

The predominant vegetation is live oak (Quercus virginiana) and Texas cedar (Juniperus ashei) (Simpson 1988:180, 301). The hilltop offers flat spaces, providing room for camps, quick and easy access to the resources of the creeks and uplands, some shade, and protection from flash floods. In the creek bottoms, tall trees shade the ground, leaving little light for understory growth, while the lower slopes of the hill are covered with small trees and a medium to heavy brush cover. 


\section{Cultural Context}

The importance of the wide variety of landform and vegetation regions in the area, along with the presence of permanent water, cannot be overemphasized in considering the history of the area. The variety of resources, including the plants and animals of differing biotic zones and the lithic resources available within a short distance, made this a rich region from the viewpoint of its prehistoric inhabitants. Problems associated with seasonal and climatic variations could be ameliorated by simply moving a few miles-and into a different biotic and/or vegetative zone. Availability of water would seldom have been a problem, for throughout the area were numerous rivers, creeks, and springs (Brune 1975). The Balcones Escarpment serves as a geographical division between the Central Texas archaeological region to the north and the South Texas region to the south (Black 1989a:39-41).

The area around Comanche Hill is an ecotone incorporating an interface of diverse ecological communities (Johnson 1967:73). These include Juniper-Oak-Mesquite Savanna in the Edwards Plateau region; Blackland Prairie in the northeast; Oak-Hickory forest in the southern part; and MesquiteChaparral Savanna in the west-central part of Bexar County.

The geographic location of the project area provides a dynamic setting for a greater diversity in riverine, uplands, and xeric vegetation and fauna. Two ecological settings dominate the project area landscape within the ecotone: uplands arid creek zones. Descriptions of the project area prior to 1900 reveal that the uplands were once dominated by tall grasses, with occasional stands of brush and mesquite (Inglis 1964).

Early descriptions (1675-1722) of plant life by Spanish observers, who left a written record of the area, suggest that mesquite and other thorny scrub were present in scattered mottes, while the land to the south was open grasslands with little or no brush (Inglis 1964:Plate 1). Historic alterations to the primary landscape include plowing, overgrazing, stream rechannelization, controlled burning, and the introduction of deep wells. These have undoubtedly lowered water tables, and altered plant and animal communities. Many springs feeding the streams emanating from the Balcones Fault are now seasonally dry (Brune 1981:75).

\section{Cultural Chronology}

\section{Prehistoric}

Several scholars have offered sound but differing arguments for cultural chronologies for central Texas. The most recent synthesis of the available chronological evidence of archaeological culture history in central and south Texas is presented below and in Table 1 (Black 1995; Collins 1995; Hester 1995). All dates are approximate and given as years before present (B.P.), i.e., before 1950.

\section{Pre-Clovis}

Although humans may have inhabited the local landscape before 11,500 B.P., current evidence does not support this. The argument that artifacts recovered from Levi Rockshelter in Travis County are older than Paleoindian (Alexander 1983:133-145) is not supported by clustered radiocarbon dates or distinct artifact and extinct fauna assemblages within welldefined stratigraphy (Collins 1995:380-381). Although human behavior is inferred on stone artifacts from Friesenhahn Cave in Bexar County (Krieger 1964) and mammoth bones at the Waco Site in McLennan County (Fox et al. 1992:51-73), these are problematic for the same reasons given for Levi Rockshelter. Additionally, several skulls of "presapiens ancestry" with "pronounced supra-orbital torus, a marked postorbital constriction, and a low sloping forehead" were found in Hitzfelder Cave in northeast Bexar County (Givens 1968:219), But no radiocarbon dates are available to substantiate their surmised antiquity. The Middle Archaic points found with the burials suggest the skeletons are more likely 5,000-6,000 years old (Givens 1968:219). As Collins (1995:380-381) offers, eroded landforms are not likely to yield solid stratigraphic proof of human occupation earlier than late Pleistocene, and if we do find earlier occupations on stable landforms, what comprises the signature of a Pre-Clovis culture? 
Table 1.Central and South Texas Chronologies

\begin{tabular}{|c|c|c|c|c|c|c|c|}
\hline \multirow{2}{*}{$\begin{array}{l}\text { Years } \\
\text { B.P. }\end{array}$} & \multirow{2}{*}{$\begin{array}{c}\text { Geologic } \\
\text { Epoch } \\
\end{array}$} & \multicolumn{2}{|c|}{ Central Texas (Collins 1995) } & \multicolumn{2}{|c|}{ South Texas (Hester 1995) } & \multicolumn{2}{|c|}{ South Texas (Black 1995) } \\
\hline & & Period & Style Intervals & Period & Style Intervals & Period & Style Intervals \\
\hline \multirow[t]{2}{*}{0} & \multirow{7}{*}{$\begin{array}{c}\text { Late } \\
\text { Holocene }\end{array}$} & Historic & & His toric & & His toric & \\
\hline & & \multirow[b]{2}{*}{$\begin{array}{c}\text { Late } \\
\text { Prehistoric } \\
260-1,200\end{array}$} & \multirow{2}{*}{$\begin{array}{c}\text { Late } \\
\text { Perdiz } \\
\text { Early } \\
\text { Scallorn, } \\
\text { Edwards }\end{array}$} & Protohistoric & & Protohistoric & \\
\hline \multirow[t]{2}{*}{1000} & & & & $\begin{array}{c}\text { Late } \\
\text { Prehistoric } \\
420-1,250\end{array}$ & $\begin{array}{c}\text { Toyah Horizon } \\
\text { Perdiz, } \\
\text { Edwards, } \\
\text { Scallorn }\end{array}$ & $\begin{array}{c}\text { Late } \\
\text { Prehistoric } \\
350-1,150\end{array}$ & $\begin{array}{c}\text { Toyah Phase } \\
\text { Perdiz } \\
\text { Austin Phase } \\
\text { Edwards , Scallorn }\end{array}$ \\
\hline & & \multirow{4}{*}{$\begin{array}{c}\text { Late } \\
\text { Archaic } \\
1,200-4,000\end{array}$} & \multirow{4}{*}{$\begin{array}{c}\text { D arl } \\
\text { Ensor, Frio, } \\
\text { Fairland, } \\
\text { Marcos, } \\
\text { Montell, } \\
\text { Castro ville, } \\
\text { Lange, Marshall, } \\
\text { Williams, } \\
\text { Pedernales, } \\
\text { Kinney, } \\
\text { Bulverde }\end{array}$} & $\begin{array}{c}\text { Tran sitional } \\
\text { A rchaic } \\
\end{array}$ & $\begin{array}{c}\text { Matamoros, Frio, } \\
\text { Ensor }\end{array}$ & \multirow[b]{2}{*}{$\begin{array}{c}\text { Late } \\
\text { Archaic } \\
1,150-2,350\end{array}$} & \multirow{2}{*}{$\begin{array}{l}\text { Fairland, Ellis, } \\
\text { Frio, Ensor, } \\
\text { Marcos, } \\
\text { Tortugas? } \\
\text { Corner Tang } \\
\text { Knives }\end{array}$} \\
\hline \multirow[t]{2}{*}{2000} & & & & $\begin{array}{c}\text { Late } \\
\text { A rchaic } \\
1,250-2,350\end{array}$ & $\begin{array}{c}\text { Desmuke, } \\
\text { Olmos bifaces, } \\
\text { Montell, } \\
\text { Marcos, Shumla }\end{array}$ & & \\
\hline & & & & \multirow{3}{*}{$\begin{array}{c}\text { Middle } \\
\text { A rchaic } \\
2,350-4,450\end{array}$} & \multirow{3}{*}{$\begin{array}{l}\text { Dimmit tools, } \\
\text { Carrizo, } \\
\text { Abasolo, } \\
\text { Tortugas }\end{array}$} & \multirow{3}{*}{$\begin{array}{c}\text { Middle } \\
\text { Archaic } \\
2,350-4,450\end{array}$} & \multirow{3}{*}{$\begin{array}{l}\text { Pedernales, } \\
\text { Morbiss, } \\
\text { Langtry, } \\
\text { Lange, } \\
\text { Kinney, } \\
\text { Castroville, } \\
\text { Bulverde }\end{array}$} \\
\hline 3000 & & & & & & & \\
\hline \multirow[t]{2}{*}{4000} & \multirow{5}{*}{$\begin{array}{c}\text { Middle } \\
\text { Holocene }\end{array}$} & \multirow{3}{*}{$\begin{array}{c}\text { Midd le } \\
\text { Archaic } \\
4,000-6,000\end{array}$} & \multirow{3}{*}{$\begin{array}{c}\text { Nolan, Travis, } \\
\text { Taylor, } \\
\text { Bell-Andice- } \\
\text { Calf Creek }\end{array}$} & & & & \\
\hline & & & & \multirow{4}{*}{$\begin{array}{c}\text { Early } \\
\text { A rchaic } \\
4,450-7,950\end{array}$} & \multirow{4}{*}{\begin{tabular}{|} 
Early Basal \\
Notched, \\
Bell, \\
Andice, \\
Early Triangular, \\
Clear Fork tools, \\
Early Comer \\
Notched, \\
Martindale, \\
Uvalde, \\
Baker, \\
Bandy, \\
Guadalupe Tools
\end{tabular}} & \multirow{4}{*}{$\begin{array}{c}\text { Early } \\
\text { Archaic } \\
4,450-7,950\end{array}$} & \multirow{4}{*}{$\begin{array}{c}\text { Bell, } \\
\text { Andice, } \\
\text { Early Triangular, } \\
\text { Clear Fork Tools, } \\
\text { Early Expanding } \\
\text { Stem, } \\
\text { Guadal upe Tools }\end{array}$} \\
\hline 5000 & & & & & & & \\
\hline 6000 & & \multirow{3}{*}{$\begin{array}{c}\text { Early } \\
\text { Archaic } \\
6,000-8,800\end{array}$} & \multirow{3}{*}{$\begin{array}{c}\text { Martindale, } \\
\text { Uvalde, } \\
\text { Early Split Stem, } \\
\text { Angostura }\end{array}$} & & & & \\
\hline 7000 & & & & & & & \\
\hline 8000 & \multirow{3}{*}{$\begin{array}{l}\text { Early } \\
\text { Holocene }\end{array}$} & & & & \multirow{6}{*}{$\begin{array}{c}\text { Lerma, } \\
\text { Scottsbluff, } \\
\text { Golondrina, } \\
\text { Early Stemmed } \\
\text { Lanceolate, } \\
\text { Angos tura, } \\
\text { Wilson, } \\
\text { St. Mary's Hall, } \\
\text { Plainview, } \\
\text { Clovis }\end{array}$} & \multirow{6}{*}{$\begin{array}{c}\text { Paleoindian } \\
7,950-11,150\end{array}$} & \multirow{5}{*}{$\begin{array}{l}\text { Scottsbluff, } \\
\text { Golondrina, } \\
\text { Early Stemmed, } \\
\text { Lanceolate, } \\
\text { Angostura, } \\
\text { Plainview, } \\
\text { Clovis }\end{array}$} \\
\hline & & \multirow{5}{*}{$\begin{array}{l}\text { Palcoindian } \\
8,800-11,500\end{array}$} & \multirow{5}{*}{\begin{tabular}{|} 
St. Mary's Hall, \\
Golondrina, \\
Barber, \\
Wilson, \\
(Dalton, \\
San Patrice) \\
(Plainvie w) \\
Folsom, \\
Clovis
\end{tabular}} & & & & \\
\hline 9000 & & & & $\begin{array}{c}\text { Paleoindian } \\
7,950-11,200\end{array}$ & & & \\
\hline 10000 & Pleistocene & & & & & & \\
\hline 11000 & & & & & & & \\
\hline & & & & & & & \\
\hline
\end{tabular}




\section{Paleoindian}

This phase spans the period estimated at between ca. 11,500-8800 B.P. in central Texas (Collins 1995:381383) and between $11,200-7,950$ B.P in south Texas (Hester 1995:433-436). Diagnostic artifacts include Clovis and Folsom projectile points. Certainly the wide distribution of Clovis points across most of North America and even into Central America suggests a wide dispersal of the people who made them (Kelly 1993; Wenke 1990:201). Within Texas's political boundaries, Meltzer and Bever (1995:47-81) have documented the presence of 406 Clovis points in 128 of 254 counties. Other artifacts associated with the Clovis culture include bifaces, prismatic blade cores and blades, engraved stones, bone and ivory points, stone bolas, ochre, and shaft straighteners.

In general the Paleoindian adaptation has been considered to be one of small bands of nomadic, biggame hunters following herds of Late Pleistocene fauna, including mammoth, mastodons, bison, camel, and horse, across North America (Black 1989b). More recently, emphasis has been placed on the wide diversity of plants and animals used for subsistence by these early Americans (Black 1989b; Hester 1983), such as turtles, tortoises, alligators, mice, badgers, and raccoons (Collins 1995:381), although they undoubtedly hunted the large animals as well (Dibble and Lorraine 1968). Known Clovis site types include killsites, quarries, caches, open campsites, ritual sites, and burials (Collins 1995:381-383; Hester 1995:433436). A Folsom interval follows the Clovis. Folsom artifacts are fairly common in central and south Texas; however, no camp sites or killsites have been found south of Bexar County (Hester 1995:434-435).

\section{Early Archaic}

Collins (1995:383) argues that the Early Archaic spans the period from 8800 to 6000 B.P. in central Texas, with three divisions based on projectile point types, while Hester (1995:436-438) identifies the Early Archaic with Early Corner Notched and Early Basal Notched dart points roughly dating between 7950 and 4450 B.P. The extinction of large herds of megafauna and the changing climate at the beginning of the
Holocene stimulated a behavioral change by the Prehistoric inhabitants of South Texas (McKinney 1981). While the basic hunter-gatherer adaptation probably remained intact, an economic shift away from big-game hunting was necessary. In general, more intensive exploitation of local resources in central Texas-such as deer, fish, and plant bulbsis indicated by greater densities of ground-stone artifacts, fire-cracked rock cooking features, and more specialized tools such as Clear Fork gouges and Guadalupe bifaces (Turner and Hester 1993:246, 256). Weir (1976) speculates that Early Archaic groups were small and highly mobile, an inference from the fact that Early Archaic sites are thinly distributed and that diagnostic types are seen across a wide area, including most of Texas and northern Mexico. Story (1985) believes that population densities were low during this period, and that groups consisted of related individuals in small bands with "few constraints on their mobility" (Story 1985:39). Their economy was based on utilization of a wide range of resources, especially such year-round resources as prickly pear, as well as rodents, rabbits, and deer (Story 1985:38).

\section{Middle Archaic}

Collins (1995:383) defines this intermediate interval of the Archaic as lasting from about $6000-4000$ B.P. in central Texas, but Hester (1995:438-441) suggests that the period between 4450 and 2350 B.P. more correctly reflects the Middle Archaic in south Texas. The Middle Archaic appears to have been a time of increased population, based on the large number of sites from this period in south and central Texas (Story 1985:40; Weir 1976:125, 128). The reasons for this increase are not known, but the amelioration of a very dry period (Altithermal) during the Middle Archaic is often seen as the primary cause (Sollberger and Hester 1972:338; Story 1985:40). On the South Texas Plains, exploitation of widely scattered, year-round resources such as prickly pear continued (Campbell and Campbell 1981:13-15), as did hunting deer and rabbit. However, a shift to concentrated, seasonal nut harvests in the riverine environments of the Balcones Escarpment seems to have occurred (Black 1989b). Weir (1976) believes that an expansion of oak on the Edwards Plateau and Balcones Escarpment led to 
intensive plant gathering and acorn processing. He also believes that the widely scattered bands prevalent in the Early Archaic now began to coalesce, at least during the acorn-gathering season, into larger groups who shared the intensive work of gathering and processing the acorn harvest (Weir 1976:126). Many researchers believe burned rock middens are a result of this endeavor (Creel 1986; Prewitt 1991; Weir 1976). Other investigators doubt this conclusion (Black et al. 1993; Goode 1991), but the exact processes which formed the burned rock middens are still a matter of controversy (Black 1989a:28; Black et al. 1997; Leach and Bousman 1998).

The common presence of deer remains in burned rock middens encourages the view that deer processing took place at these sites (Black and McGraw 1985:278; Weir 1976:125). Bison bone is encountered in archaeo-logical sites in central and south Texas, at least occasionally, during all but the earliest part of the Middle Archaic (Dillehay 1974). There has been a tendency to equate presence of burned rock middens with absence of bison (Prewitt 1981); however, examinations of several recent faunal reports show that after about 4500 B.P. bison and burned rock middens are contemporaneous, although not at the same sites, at least in the southern Edwards Plateau and northern South Texas Plain (Meissner 1993).

\section{Late Archaic}

Collins (1995:384) dates the final interval of the Archaic in central Texas to approximately 4000-1200 B.P. Hester believes the Late Archaic in south Texas may better be defined as between 2350 and 1250 B.P. Some researchers believe populations increased throughout the Late Archaic (Prewitt 1985), while others feel populations remained the same or fell (Black 1989a:30). Prewitt (1981:80-81) asserts that the accumulation of burned rock middens nearly ceased during the course of this period; however, excavations at the Blue Hole site in Uvalde County (Mueggenborg 1994:1-74), the Honey Creek midden in Mason County (Black et al. 1997), the Jonas Terrace site in Medina County (Johnson 1995), and the Mingo site in Bandera County (Houk and Lohse 1993:193-
248) provide evidence that large cooking features up to $15 \mathrm{~m}$ in diameter were still very much in use (see also Black et al. 1997). Subsistence is assumed to have become less specialized and focused on acorns, in favor of a broad spectrum subsistence base (Black 1989a:30). By about 1450 B.P., bison had again disappeared (Dillehay 1974).

Although inhabitants of the South Texas Plain near Brownsville and Rockport had begun to make pottery by about 1750 B.P., the northern part of the plain was still "pre-ceramic" until 1,000 years later (Story 1985:45-47). Late Archaic points tend to be much smaller than Middle Archaic points. The most common are Ensor and Frio types (Turner and Hester 1993:114,122), both of which are short, triangular points with side notches. The Frio point also has a notched base (Turner and Hester 1993:122).

\section{Transitional Archaic}

A late subperiod or interval of the Late Archaic is frequently referred to as the Terminal Archaic or Transitional Archaic. Weir (1976) defines the Terminal Archaic as 1650-1150 B.P., while Turner and Hester (1993) cite data placing the Transitional Archaic as 2250-1250 B.P. Although Hester (1995) may lump current data into a Late Archaic period, he cautions that more evidence will likely result in what may be termed as a "Terminal Archaic" period during the latter part of the Late Archaic in south Texas. This Terminal Archaic period is represented by diagnostic projectile points such as Ensor, Frio, and Matamoras points which appear to overlap the Late Archaic and Late Prehistoric periods (Hester 1995:442). Weir (1976) believes this marked a transition period to localized area sites, a disappearance of burned rock middens and bison, and a reappearance of highly mobile hunters and gatherers. Others (Black and McGraw 1985; Peter 1982; Skelton 1977) argue that in some locations burned rock middens did not disappear and sites were more intensely occupied during the Transitional Archaic period. 


\section{Late Prehistoric}

Collins (1995:385) recognizes that the commonly used date of 1200 B.P. for the end of the Archaic and beginning of the Late Prehistoric in central Texas is arbitrary, and Hester (1995:442) acknowledges the problematic issue of selected tools appearing at both Late Archaic and Late Prehistoric sites. A series of distinctive traits marks the change from the Archaic to the Late Prehistoric period, including the technological shift to the bow and arrow and the introduction of pottery to central Texas and the northern South Texas Plain (Black 1989a:32; Story 1985:45-47). Most researchers agree the early Late Prehistoric period was a time of population decrease (Black 1989a:32). Even though small burned rock middens associated with Scallorn and Edwards points have been found (Goode 1991:71; Houk and Lohse 1993:193248), they are rare. Settlement shifts into rockshelters such as Scorpion Cave in Medina County (Highley et al. 1978), Classen Rockshelter in northern Bexar County (Fox and Fox 1967), and Timmeron Rockshelter in Hays County (Harris 1985) have been noted.

Beginning rather abruptly around 650 B.P., a shift in technology occurred. This phase is characterized by the introduction of blade technology, the first ceramics in central Texas (bone-tempered plainwares), and the appearance of Perdiz arrow points and alternately beveled bifaces (Black 1989a:32; Huebner 1991:346). Prewitt (1985) and Black (1989a) suggest this technology encroached from north-central Texas. Patterson (1988), however, notes the Perdiz point was first seen in southeast Texas by about 1350 B.P., and was introduced to the west some 600-700 years later. Hester (1995:444) recognizes this phase as the "best documented Late Prehistoric pattern" throughout south Texas, with dates ranging from ca. $650 / 700$ to 300/350 B.P.

Steele and Assad Hunter (1986) argue for the occurrence of a distinct change in diet between the Late Archaic and the Late Prehistoric components in two sites in Choke Canyon Reservoir in south Texas. Analysis of the number of identified specimens (NISP) shows a marked increase in artiodactyl elements present during the late Late Prehistoric, an increase largely due to the addition of bison to the "menu"
(Steele and Assad Hunter 1986:468). Huebner (1991) suggests that the sudden return of bison to south and central Texas resulted from a more xeric climate in the plains north of Texas, and increased grassiness in the Cross-Timbers and Post Oak Savannah in north central Texas, forming a "bison corridor" into the South Texas Plain along the eastern edge of the Edwards Plateau (Huebner 1991:354-355).

\section{Historic}

The end of the Late Prehistoric and beginning of the Historic period in both central and south Texas should be characterized by written accounts of European contact with indigenous groups. Collins (1995:386387) offers that the Historic period then begins ca. 260 B.P. in central Texas; however, in south Texas Hester (1995:450-451) agrees with Adkins and Adkins (1982:242) when he suggests that the indigenous groups may have been affected by European influence but we are only able to observe the materials in the archaeological record because the written accounts simply are not available. He would rather label this largely unknown period "Protohistoric."

The cultural context for the historic groups in the study area is largely conditioned by the presence of outside ethnic groups and regional power struggles. The numerous small groups of Coahuiltecans encountered by the early explorers and later Spanish intrusions are addressed in many sources (Campbell 1983; Campbell and Campbell 1985; Hester 1989; John 1975; Newcomb 1961; Swanton 1952). The various later intrusive groups, such as Tonkawa, Lipan Apache, and Comanche, are also described by numerous researchers (Ewers 1969; Hester 1989; Jones 1969; Kelley 1971; Newcomb 1961, 1993; Sjoberg 1953a, 1953b).

At the beginning of the seventeenth century, many south Texas Indian groups were being pushed northward by continual Spanish expansion. By the mid-seventeenth century, a new pressure on the Indians indigenous to the area began to come from the north: a nomadic group, the Apache, who were adapted to a more Plains-lifeway style of bison hunting, especially once they acquired horses from 
the Spaniards (Campbell and Campbell 1985:27). The Apache were later displaced by another group of nomadic, bison-hunting Indians-the Comanchefrom the High Plains of Texas (Campbell 1991:111).

A combination of migration, demoralization, innergroup conflict, disease, and death due to warfare fragmented the native Indian groups, and forced continual mixing and remixing among them (Bolton 1915; Campbell 1975, 1991:345; León et al. 1961). Most of the native languages have been lost, although recent attempts at reconstruction are enlightening (e.g. Johnson 1994; Johnson and Campbell 1992). The establishment and relocation of Spanish Catholic missions along the San Antonio River in the late 1600s and early 1700 s induced many groups to seek the relative comfort and protection offered by a sedentary, apparently well-fed, and peaceful coexistence (Campbell and Campbell 1985; Chipman 1992; de la Teja 1995; Habig 1968a, 1968b; Hard et al 1995; Inglis 1964). Although fear of the invading Apache and Comanche pressured many of the Indians to seek the protection of missions, they were now exposed to the exploitation of the Spanish (Campbell 1975:2, 1991:346-347).

Few landowners dared to live on their outlying lands until about 1749 , when a treaty with the Apaches brought peace for awhile (de la Teja 1995:100). Apaches continued to range over the area between San Antonio and Laredo until the early 1800s, pushed southward by the invading Comanche who had moved into the Hill Country of central Texas (Campbell and Campbell 1985:27). Weary of warfare with the Comanche, a few Apaches were beginning to seek asylum in the missions (McGraw and Hindes 1987:367; West 1904:50).

In the autumn of 1785 , a peace treaty was agreed to in Santa Fe between Don Juan Bautista de Anza, representing the Spanish Crown, and Cuera (Leather Jacket), representing the Comanche. The treaty began a period of peaceful coexistence in what is today Bexar County, during which Comanches brought hides, meat, and tallow to San Antonio to trade for goods and services not available elsewhere, such as blacksmithing and gun repair (Fehrenbach 1978:221-224; Poyo and Hinojosa 1991:125-126). The few
Comanches who entered the missions were apparently women and children who were captured during punitive raids by Spanish soldiers (Campbell and Campbell 1985:26).

The newly formed government of Texas gave land grants that were large, consisting of around 5,000 acres for each property. Spanish cattle ranching became prevalent south and southeast of San Antonio (Jackson 1986). However the political turmoil that permeated early Texas caused the near-complete European desertion of San Antonio following the Mexican War for Independence (Fehrenbach 1983).

Around 1840 settlers from Germany and AlsaceLorraine and from other regions of the United States began to flood into San Antonio. Many of the Germans moved into the Hill Country to the north, settling into communities, and raised sheep or cattle (Freeman 1994:5-9). As the sheep and cattle markets emerged in the 1880s, ranchers and farmers settled farther away from San Antonio (Flanagan 1974; Lehmann 1969; Nickels et al. 1998). The introduction of twentiethcentury technologies such as mills and improved methods of production have shaped the area as it exists today (Fox et al. 1989).

\section{The Mystique Surrounding the Hill}

Comanche Hill is a prominent landmark in northeast Bexar County. As such, it carries with it folklore and legendary "baggage" that may or may not be historically correct, e.g., the Mormon massacre and buried gold. The fact that Comanche Hill lies adjacent to the old Nacogdoches-to-Bastrop-San Antonio Camino Real (Royal Road) indicates that the lookout was a significant and frequently used landmark during the eighteenth and nineteenth centuries (McGraw et al. 1991).

The land on which the hill is located was part of Texas Land Grant Survey \#196 which granted 735,620 square varas $(1,476$ acres), or one-third of a league, of land to James Conn (Bexar County Deeds and Records [BCDR] Bexar County Courthouse, San Antonio, Texas, Volume 334) from Harrisburg County (now Harris County and the city of Houston) (Henson 
1996:480). The land was surveyed for Conn by the Bexar court district surveyor, John James, in April 1847 (BCDR, 334). James resided at 123 West Commerce, in San Antonio. His house was, for many years, the only house in the city that had a fireplace and chimney (Chabot 1937:336). His name on a survey record was highly respected and his work accepted as without error (Strong 1996:905-906). Conn immediately consigned his right to the land to Peter W. Gray (BCDR, 334). Gray came to Texas in 1838, and studied law in Houston. He was a lieutenant in the Milam Guards, served as a captain in the 2 nd Brigade of the Texas Army in 1840, represented Harris County in the Fourth Texas Legislature, became a district judge, and subsequently served in the House of the Confederate Congress. Gray County, which was a part of Bexar Territory, is named in his honor (Abbe 1996:296).

Gray immediately passed the title of Survey \#196 to Alexander Patrick, who immediately transferred his claim to Ludovic Colquhoun (BCDR, 334), James's mentor and partner in the land surveying business (Strong 1996:905-906). Colquhoun was a senator from San Antonio with numerous land holdings in the area. He was taken prisoner by General Woll and sent to Perote prison in Mexico in 1842 . He was.released in 1844. He later became a Confederate States Depositary in 1865 (Cutrer 1996:231-232).

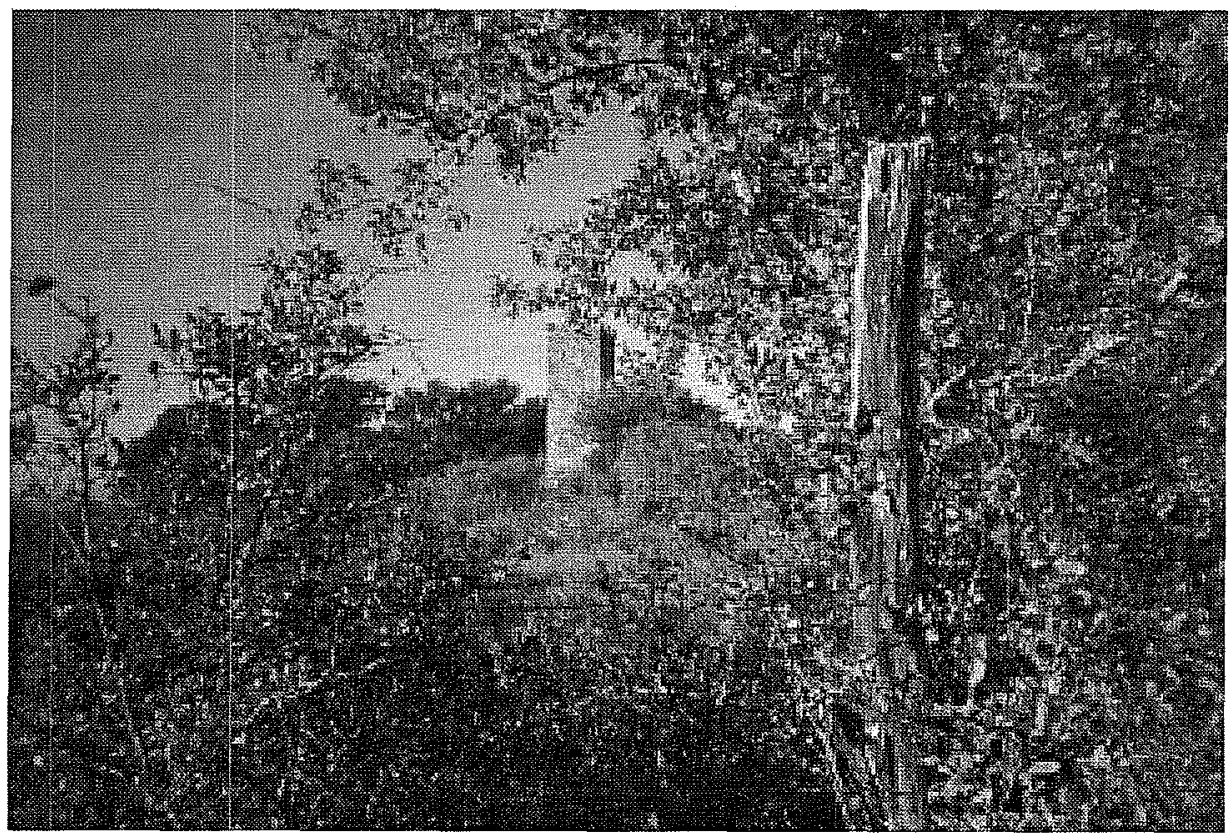

Figure 4. Photograph of the tower constructed by Colonel Coppock.
By 1890 claim to the land surrounding Comanche Hill belonged to S. D. and Loretta Calder of Galveston, apparently absentee landowners (BCDR, 709:295). Their interest in the land either as pure investment or good intentions to eventually live on the parcel could not be determined. Nevertheless, they sold 524.6 acres of the property in July 1890 to Gustav and Adolph Reeh of Bexar County for $\$ 3,500$ (BCDR, 68:462464).

As the survivor, Gustav Reeh eventually sold the southern three-quarters of Comanche Hill parcel to Colonel Edward H. Coppock in February 1923 for a sum of $\$ 6,000$. Colonel Coppock retired from 44 years in the U.S. Army where he fought against the Apaches and Sioux, served in the Spanish-American War, the Philippine Insurrection, and World War I (San Antonio Express Magazine [SAEM], 11 January 1948). He paid $\$ 1,000$ down and agreed to pay the remaining $\$ 5,000$ over a five-year period (BCDR, 709:295). Colonel Coppock and his two sons, Edward Jr. and E. S., along with a Mexican laborer, are responsible for the structural concrete and stone foundations that are now on Comanche Hill. Between 1923 and the Colonel's death in 1948, they constructed the highly visible castle-like tower (Figure 4), a stone lodge, several outbuildings, a 2,500-gallon water tower, a Spanishstyle corral, picnic tables, a barbecue pit, a tennis court, and some smaller homes since destroyed by fire. The

tower, modeled after "a similar structure erected by William the Conqueror at the site of the Battle of Hastings in the 11 th century" (SAEM, 11 January 1948; San Antonio News, 14 November 1972) bears the colonel's initials and a date of 1928 above one of its openings. Unfor-tunately, Colonel Coppock died in 1948, before his U-shaped castle could be constructed over the foundation he laid.

After the colonel's death, the parcel was divided and changed hands several 
times. Finally, with the help of the Resolution Trust Company (San Antonio Express-News [SAEN], 24 January 1993), the city of San Antonio acted to procure the colonel's property and other smaller parcels around it for a total of 96 acres. Soon after acquiring the land, the city began planning the park's development (SAEN, 3 June 1994; 7 May 1997).

Although not well documented, the historic occupation of the area by Native Americans-particularly Comanche-during the past few hundred years is was reported by European settlers. The nomadic Comanche pushed into the prairies around San Antonio from the north in the mid-1700s, dominating the lands, and forcing the local tribes to seek refuge in the five Spanish missions (Campbell 1991). Written accounts of the bravery and fierceness of Comanche warriors around San Antonio begin in the 1830s, thought to be in response to surveyors and land seekers "invading" the Indian hunting grounds outside San Antonio, and perhaps being encouraged and influenced by Mexican generals still smarting from the defeat at San Jacinto (Wilbarger 1985:82, 152-153). An isolated incidence of horse theft by a Comanche warrior is recorded near Bastrop (Wilbarger 1985:239-240). In October 1838, a group of Comanches attacked a survey party about five miles from San Antonio (Wilbarger 1985:81). Hostilities between the Comanches and white settlers around San Antonio, Gonzales, and elsewhere along the Guadalupe River intensified in 1838 and 1839 (Wilbarger 1985:287-290). The Comanches often took whites as prisoners, and in an attempted exchange of prisoners and treaty process, fought the settlers and military in San Antonio at the Council House Fight in March 1840 (Wilbarger 1985:22-25). Later that same year, approximately 200 Comanches raided San Antonio, making off with several horses, and retreating toward the Guadalupe River (Wilbarger 1985:73). In 1841 a party of Comanches temporally trapped Texas Ranger Colonel "Captain Jack" Hays on Enchanted Rock. Hays and his Rangers again encountered a group of about 75 Comanches near the Pedernales River in 1844 (Wilbarger 1985:75-78). Although not directly attributed to the Comanches, Dr. Witter was killed by Indians near Gonzales in the spring of 1842 (Wilbarger 1985:608). Relations between the settlers and Comanches were not totally soured, however. By 1844 Comanche riders were riding against the horsemanship skills of Hays's Texas Rangers and Mexican rancheros in friendly competition near San Pedro Springs north of San Antonio (Wilbarger 1985:66, 290-295). Yet outside the city, particularly in the hill country to the north, Indian depredations continued throughout the 1860s and 1870s (Wilbarger 1985:643-659).

\section{Archaeological Investigations}

\section{Previous Investigations}

Professional archaeology has been conducted in Texas for over 60 years, but some regions have been more intensely studied and documented than others. The formative groundwork for Texas archaeology was laid almost 45 years ago (Collins 1995) with the publication of the Handbook of Texas Archeology (Suhm et al. 1954). Since that time, a comprehensive chronological sequence has been worked out for central Texas (Black 1989a, 1989b; Collins 1995; Turner and Hester 1993); although not without considerable discussion over both details and fundamental assumptions (Collins 1995; Johnson and Goode 1994; Potter and Black 1995). Extensive work has been carried out in south Texas only within the past three decades (Hester 1995), resulting in a cultural chronology for that region that is less well understood and more explicitly tentative. In Bexar County, interest in archaeology was heightened when the Witte Memorial Museum of San Antonio was established in 1926 and began conducting research locally and in adjacent areas such as the Pecos River region (Fehrenbach 1978). Artifacts from those expeditions were displayed at the museum, increasing local interest in the region's prehistoric past. During the last two decades, CAR activities and those the Southern Texas Archaeological Association (STAA) have bolstered the identification and preservation of cultural resources in Bexar County. Due substantially to the efforts of these two institutions, more than 1,200 sites have been recorded in the county.

Large-scale surveys covering thousands of acres along the Balcones Escarpment and the eastern Edwards Plateau have been highly effective in discovering archaeological sites. Seventy-two sites were recorded at Camp Bullis in northern Bexar County (Gerstle et al. 1978). The survey covered the watersheds of upper 
Cibolo Creek, Ranger Creek, and upper Salado Creek. Thirty-four of those sites were associated with diagnostic lithic tools from the Paleoindian through Late Prehistoric periods. Thirty-four sites were recorded during a survey of the East and West Elm Creek branches of the upper Salado Creek in the Encino Park area of northern Bexar County. Those sites contained Paleoindian through Late Archaic components (McGraw et al. 1977:10-29). Thirty-one prehistoric sites dating from the Paleoindian through Late Prehistoric periods were found during a survey of the upper Cibolo in southern Kendall County (Bass and Hester 1975:9-24; Kelly and Hester 1976:29). McGuff recorded 28 prehistoric sites along Leon Creek in northern Bexar County in 1970 and 1971 (site reports on file at CAR). A survey of lower Medio Creek by McGraw (1977) documented 15 prehistoric sites. In 1987 CAR documented 52 sites along the Medina River for a cultural assessment of the area to be affected by the proposed Applewhite Reservoir (McGraw and Hindes 1987). Nickels et al. (1998) surveyed Lackland Air Force Base in southwest Bexar County and recorded 68 prehistoric sites. Nickels (1998) surveyed along Cibolo Creek in southern Kendall County and documented seven prehistoric sites. These recent and on-going projects discussed above have direct implications for prehistoric cultural resources within the area surrounding Comanche Hill.

In northeast Bexar County, the area around Comanche Hill is rich in prehistory. A prehistoric lithic quarry and workshop (41BX68) of undetermined age was documented and tested by McGraw and Valdez (1978) near Elm Creek and Loop 1604, approximately 1.6 $\mathrm{km}$ west of Comanche Hill. A lithic scatter (41BX564) with flakes, tested cobbles, and cores has been documented near Loop 1604 and Nacogdoches Road (Fox 1982). A scatter of cores and flakes (41BX401) was documented near Lookout Road and Loop 1604 (Jaquier 1976). At nearby Elm Creek, Katz et al. (1987) excavated a multicomponent site which consisted of intensive camping and cooking around a waterhole formed around 5,000 to 7,000 B.P.

Two polyhedral blade cores found on Comanche Hill were documented by Kelly (1992:29-33). Over the years the hill has apparently been heavily collected. Kelly (1992) reviewed one private collection and identified the points as predominantly Late Archaic through Late Prehistoric (4000-260 B.P.).

In 1992 State Archaeological Steward H. Ray Smith and volunteers from the STAA, CAR, and the Office of the State Archaeologist Steward Network conducted a pedestrian survey of Comanche Hill. They documented three areas of prehistoric cultural material (Smith et al. 1992): a burned rock scatter and a small lithic artifact concentration on the southwestern lower slopes of the hill; and a large lithic scatter near the southern, upper lip or edge of the hill (Figure 2). Upon completion of the survey Smith's preliminary assessment (copy on file at CAR) was that the hill should be designated a State Archaeological Landmark (SAL) and recommended as eligible for inclusion on the National Register of Historic Places (NRHP).

\section{The Current Project}

\section{Project Goals}

The project goals focused on archaeological issues that could be addressed by the types of data obtained through pedestrian survey combined with limited shovel and backhoe testing. The topics addressed were site type, distribution, density, size, depth, and stratigraphy. The theoretical framework is structured around patterns of settlement, mobility, subsistence, and social systems for the central Texas region. The project also allowed for analyzing the effectiveness of shovel testing in systematic intervals versus areas of high site potential.

The goals of the project were to:

1) locate and record cultural locations and sites in the project area using a systematic survey methodology;

2) measure, quantify, and analyze site type, distribution, density, and size, as well as depth and stratigraphy; and

3) measure and quantify the lithic collection and to place the diagnostic artifacts within the regional time frame. 


\section{Methodology}

\section{Prefield Preparation}

Before the official survey began, the project archaeologist inspected the project area to better understand the topography, surface visibility, and site potential. A thorough review of the literature pertaining to the area was conducted. Previous survey notes and maps compiled by $\mathrm{H}$. Ray Smith were reviewed. Site and survey reports from the area were examined. USGS 7.5 minute quadrangle maps, a Bexar County soils survey book, and a geological atlas sheet were consulted. Finally, records at the Texas Archaeological Research Laboratory (TARL) were consulted to check for previously recorded sites in the area.

\section{The Survey}

The pedestrian survey began in the southeast corner of the project area. Surveyors were organized in twoperson teams. Each team consisted of an experienced surveyor and a less-experienced UTSA student. The teams were spaced $30 \mathrm{~m}$ apart and walked transects on a specified compass bearing. The ends of each transect were marked with orange flagging tape, showing the compass bearing, date, transect letter (A-GG), and the initials of the team members on that particular transect. Each team worked in a leapfrog manner using the pace-and-compass method. Using a hand-held compass, the first team member would guide the second member forward to a station $30 \mathrm{~m}$ distant. Each station was flagged with toilet paper. Team members meandered between stations to insure better surface coverage. When an artifact was found, orange flagging tape was placed under the artifact, as well as in a tree or bush above it. Distance between crews was such that there was constant communication regarding discovered artifacts and the crew chief was able to examine all finds. If the artifacts were insufficient in number to constitute a site by definition (five artifacts in a five-square-meter area), they were recorded on a special form as isolated finds. The only prehistoric materials collected from the surface were a projectile point, a scraper, four cores with refit flakes, selected bifaces, and all chipped stone recovered from shovel tests was collected.
When the artifacts or features present constituted a site by definition, abundant flagging tape was hung in the trees to facilitate returning to the site for further documentation. Upon completion of the pedestrian survey and shovel tests, sites were revisited by the project archaeologist and crew members. Each site was intensely examined to further determine the extent of cultural material present on the surface. At least two shovel tests were placed on each site to determine approximate depth of the site. A length of rebar was driven into the ground as a site datum. Universal Transverse Mercator (UTM) coordinates were obtained at the datum using a hand-held Trimble Navigation Global Positioning System. An aluminum tag was attached to each datum bearing the state trinomial assigned by the Texas Archaeological Research Laboratory, UTM coordinates, date, and "CAR-UTSA." Finally the sites were mapped using a Total Data Station (TDS).

\section{Laboratory Methods}

Artifacts were brought to the laboratory at the end of each day in the field. Once there, each sample's provenience was verified. Samples were then placed in appropriate containers before being moved to a special storage area to await analysis. Artifacts were washed by laboratory personnel using water and toothbrushes. Once the artifacts were washed, they were allowed to air dry on mesh racks before being transferred to cardboard flats for temporary storage. These flats were placed on shelves and organized by site. Throughout this process the provenience information was kept with the materials. Once the fieldwork was completed and all the artifacts had been processed, laboratory personnel catalogued the artifacts using an Excel spreadsheet. All artifacts, raw materials, and project-related documentation are curated in archival-quality storage at CAR

\section{Mapping}

Data collected in the field was downloaded into a permanent database to create site maps and an overall map which was then superimposed over the planned development map provided by the city. 


\section{Results of the Current Investigation}

\section{The Artifacts}

Only three time diagnostic artifacts (see Appendix A) were recovered during the 96-acre survey: a badly damaged Middle Archaic Pedernales point; a crudely made Early Archaic Guadalupe biface; and a Late Prehistoric or possibly Paleoindian blade core with two refit blades. Such a paucity of diagnostic tools in an area that contains both a large prehistoric quarry and open campsite suggests that the area has been heavily collected by artifact hunters. Besides being in a heavily populated area and accessible to the public for years, one collection by a previous landowner has been examined (Kelly 1992). The collection consisted of predominantly Late Archaic Ensor and Late Prehistoric Edwards points, although a single Early Archaic Angostura point, thought to have been curated, and two Clovis polyhedral blade cores were also found (Kelly 1992:29; Collins and Headrick 1992). In addition to the diagnostic tools described in the following sections, Smith et al. (1992) collected 16 non-diagnostic bifaces while surveying the project area. During the current project, 7 CAR collected two additional cores with refit flakes, one scraper, and raw material samples for adding to a CAR database and type collection on raw material source studies.

\section{Pedernales Dart Point}

One of the most common dart point types in central Texas, where they are frequently associated with burned rock middens (Black and McGraw 1985:113), Pedernales points also are found in south Texas and as a minor type in the Lower Pecos (Suhm et al. 1954:468). Although Hester (1995:439; Turner and Hester 1993:171) continues to date the Middle Archaic in south Texas from 4450-2350 B.P. (following Hall et al. 1986), he similarly dates Pedernales about 3950 3150 B.P. Johnson (Johnson and Goode 1994:29-30) sees the Pedernales style as part of a BulverdePedernales-Montell cultural continuum in the first part of the Late Archaic.

A badly damaged proximal end of a Middle Archaic Pedernales point (Figure 5) was found on the lower southwestern slope of the hill (see Figure 2). It is made of brown (10YR 5/3) chert with lateral banding. Although the specimen appears to be of finegrained chert, there is evidence of step fracturing on both the dorsal and ventral surfaces. One shoulder has been broken off

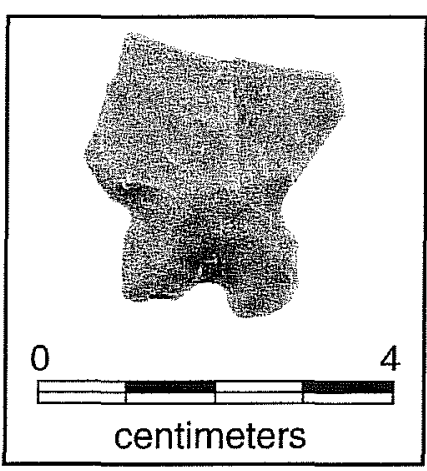

Figure 5. Pedernales dart point from $41 B X 1257$. due to an indeterminate cause, and its distal end has been snapped postdepositionally. Because of the condition of the specimen, no measurements were taken. There is no evidence of burning, serration, or beveling.

\section{Guadalupe Biface}

The Guadalupe biface is thought by some archaeologists to be a tool which may have functioned as a woodworking implement or, alternatively, as part of a hide-defleshing kit (Black and McGraw 1985:149; Goode 1989:135; Sollberger and Carroll 1985). Chronologically, the Guadalupe tool was only produced for a brief portion of the Early Archaic, ca. 6650-5250 B.P. Hester (1995) associates Guadalupe tools with an "Early Corner-Notched Horizon" which ranges from ca. $7950-5450$ B.P.

Guadalupe tools have been found from the lower Guadalupe River west to the Rio Grande, encompassing the Nueces River drainage, and northward onto the southern and eastern margins of the Edwards Plateau (Highley 1984). The distribution pattern is apparently related to the river drainage system flowing off the plateau toward the Gulf Coast, although upland occurrences also are reported. This tool form is most frequently found along the lower and middle Guadalupe River and in the upper reaches of the Medina-San Antonio River basin (Black and McGraw 1985:142, 146, Table 14, Figure 29; Brown 1985:95-102; Hester 1980:147-149; Gerstle et al. 1978:102, Table 8). 
The Guadalupe tool from Comanche Hill (Figure 6) was found on the southwestern edge of the top of the hill (see Figure 2). It is made from a light brownish (10 YR 6/2) chert and has been bi-directionally flaked on three sides with flake removal running perpendicular to the axis of the artifact. Because this specimen is fashioned from coarse-grained chert, series of flake scars terminating in hinge and step fractures are evident on all surfaces. Although smaller step fractures are evident on the bit, suggesting limited use, the predominance of large flake scars and remaining cortex on its dorsal surface suggest that the tool was discarded during its early stage of production. Measurements for the Guadalupe tool are as follows:

$\begin{array}{lr}\text { Dorsal length: } & 124 \mathrm{~mm} \\ \text { Ventral length: } & 89 \mathrm{~mm} \\ \text { Max. bit width: } & 52 \mathrm{~mm} \\ \text { Max. tool width: } & 41 \mathrm{~mm} \\ \text { Max. tool thickness: } & 52 \mathrm{~mm} \\ \text { Bit thickness: } & 37 \mathrm{~mm} \\ \text { Max. depth of bit } & \\ \text { facet concavity: } & 0-.3 \mathrm{~mm} \\ \text { Bit facet or } & \\ \text { ventral end angle: } & 130 \% \\ \text { Bit spine-plane angle: } & 70 \%\end{array}$

\section{Blade Core}

Because of their size and the size of their flake scars, two polyhedral blade cores previously found on Comanche Hill were thought by Kelley (1992) to date to the Late Prehistoric interval, ca. 260 to 1200 B.P. However Collins and Headrick (1992) challenged his assessment and suggested that the blades removed would have been similar in size to Clovis blades, dating to ca. 10,800 to 11,500 B.P.

Additional studies are required to state whether the Comanche Hill blades and core collected during the current CAR project are from either interval. They are made of brown (10YR 5/3) fine-grained chert with coarse grained inclusions. Blades have been removed from two thirds of the core. Six fresh flake scars removed from lightly patina-covered scars provide evidence for at least two episodes of reduction. Two of the blades refit to the core (Figure 7); a third blade (Figure 8) is not from the core but is a gray (10YR 6/ 1), fine- to medium-grained chert. This third blade exhibits heavy patina on its dorsal surface, and a fresh surface on its ventral surface where it has been removed from the core. Two additional fresh scars on its dorsal surface have resulted from adjacent blade removal or removal attempts.

Attributes for the core and blades are given below. 


\section{Core (Figure 7a)}

Max. diameter: $\quad 90 \mathrm{~mm}$ Max. length: $\quad 121 \mathrm{~mm}$ \# of flake scars w/slight patina surface: 4 \# of fresh flake scars: 3 Max. blade face length (older surface): $91 \mathrm{~mm}$ Min. blade face length (older surface): $85 \mathrm{~mm}$ Max. blade face length (fresh surface): $85 \mathrm{~mm}$ Min. blade face length

(fresh surface): $76 \mathrm{~mm}$ Max. facet width (older surface): $44 \mathrm{~mm}$ Min. facet width (older surface): $16 \mathrm{~mm}$ Max. facet width (fresh surface): $27 \mathrm{~mm}$ Min. facet width (fresh surface): $17 \mathrm{~mm}$

\section{Refit blade \#1 (Figure 7b)}

Max. length:

$87 \mathrm{~mm}$

Max. width: $29 \mathrm{~mm}$

Max. thickness: $16 \mathrm{~mm}$ \# of dorsal ridges: 2

Refit blade \#2 (Figure 7c)

Max. length: $\quad 74 \mathrm{~mm}$

Min. width: $\quad 25 \mathrm{~mm}$

Max. thickness: $10 \mathrm{~mm}$

\# of dorsal ridges: 1

\section{Blade \#3 (Figure 8)}

Max. length: $\quad 86 \mathrm{~mm}$

Min. width: $3 \quad 8 \mathrm{~mm}$

Max. thickness: $13 \mathrm{~mm}$ (above hinge) \# of dorsal ridges: 2

Figure 8. Single blade recovered from 41BX1258. left: dorsal view; right: ventral view

\section{a}

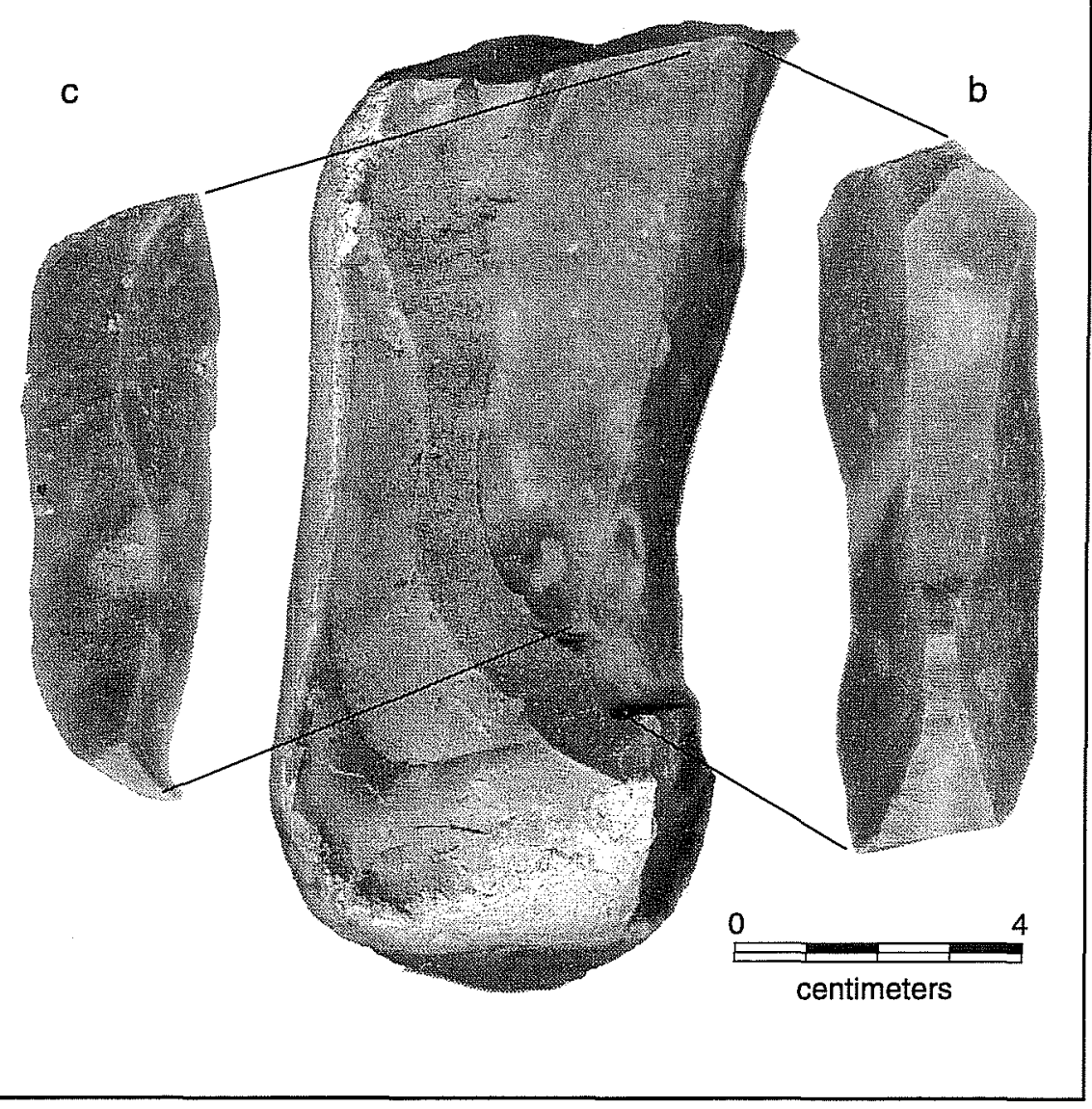

Figure 7. Blade core with refit blades from $41 B X 1258$. 


\section{The Sites}

One prehistoric open campsite and two lithic procurement sites were documented on the 96-acre parcel. The archaeological sites identified by Smith et al. (1992) were relocated, and having the advantage of a fall survey with better surface visibility, CAR surveyors determined that their boundaries were actually encompassed within a much larger site, 41BX1257 (see Figure 2). A Middle Archaic Pedernales projectile point, a crudely made Guadalupe Biface, and a Late Prehistoric or Paleoindian blade core with refit blades were the only diagnostic artifacts found during the survey. Two other cores with refit flakes were also recovered. Although the project's goals and research design focused on prehistoric occupations, numerous notes (on file at CAR) were made regarding the historic foundations and wall remnants present on, and near the top of the hill.

\section{$41 B \times 1256$}

41BX1256 (Figure 9) is a medium-size (ca. $832 \mathrm{~m}^{2}$ ) prehistoric lithic scatter of undetermined age located on alluvial Trinity Frio (Tf) soil (Taylor et al. 1991: Sheet 23). The site lies on the eastern immediate slope of an intermittent drainage and its western edge has been dissected by the drainage (Figure 2). Nineteen cores, 20 flakes, two tested cobbles, and two bifaces were observed on the surface. Four shovel tests dug to $50 \mathrm{~cm}$ below the surface produced no cultural material. Trinity Frio soils are commonly found along smaller drainages and is subject to frequent scouring or shifting (Taylor et al. 1991:33), and the site has been heavily disturbed by erosion.

\section{BX1257}

\section{Prehistoric Component}

41BX1257 is a large (ca. 16 acres) open campsite and lithic quarry with two identified artifact concentration areas (Figure 10). Surveyors observed numerous cores and flakes completely surrounding the upper elevations of the hill where raw materials naturally outcrop in all directions, except on the southwestern edge where the lithic scatter extends downslope toward an intermittent drainage (Figure 2). A core with refit

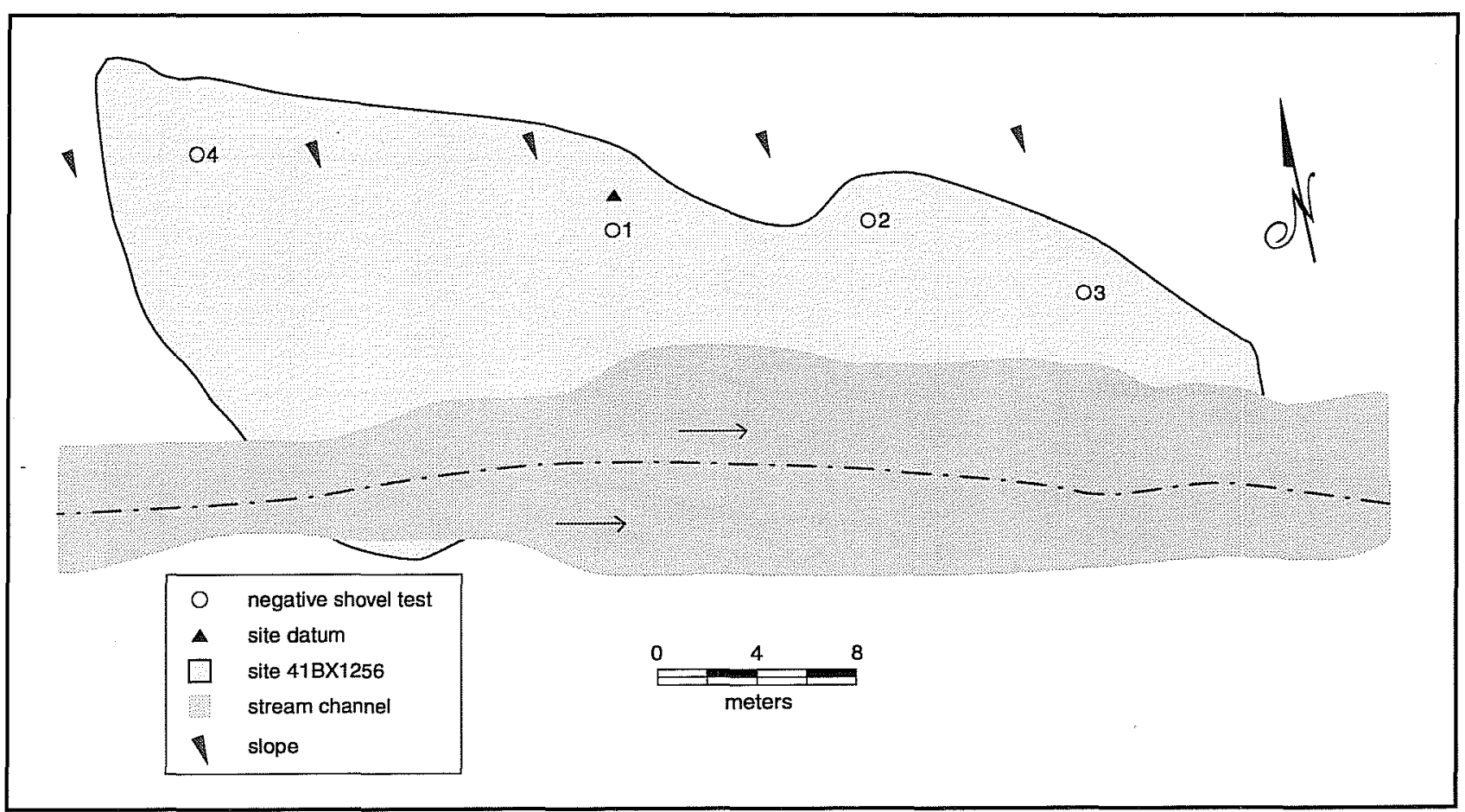

Figure 9. $41 B \times 1256$ site plan. 
This page has been

redacted because it

contains restricted

information. 
This page has been

redacted because it

contains restricted

information. 


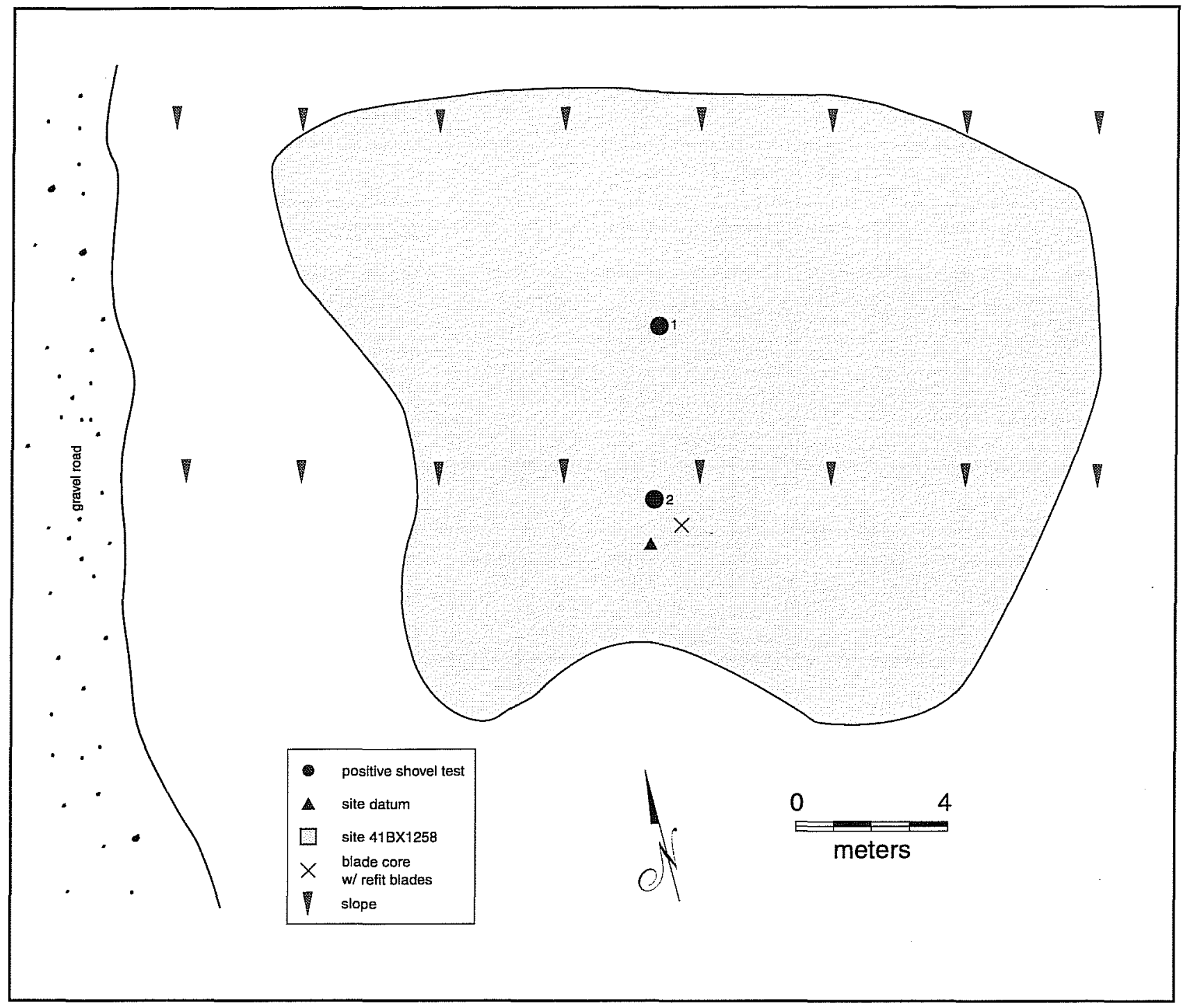

Figure 12. 41BX1258, site plan.

1991: Sheet 24), on a natural ledge not subjected to frequent flooding, scouring, or severe erosion. Two shovel tests revealed cultural material to $20 \mathrm{~cm}$ below the surface (Appendix A).

\section{Conclusions and Recommendations 41BX1256}

41BX1256 is highly disturbed from natural and artificial means. Because of the absence of in situ archaeological deposits, the site is of little or no archaeological significance, and therefore ineligible for inclusion in the National Register of Historic Places. We recommend that the planned construction which will impact $41 \mathrm{BX} 1256$ be allowed to proceed without further consultation with the city of San Antonio or the Texas State Historic Preservation Officer (SHPO). 


\section{BX1257}

\section{Prehistoric Component}

The prehistoric component of 41BX1257 is a sparse, continuous scatter of cores and flakes typical of a prehistoric lithic quarry. The component has been moderately to heavily disturbed, except in Concentrations Areas 1 and 2. Concentrations Areas 1 and 2 appear to be minimally disturbed, and based on the presence of subsurface cultural material found in 21 of 22 shovel tests in those two areas, they should be avoided by planned construction if possible. If avoidance is impossible, we recommend further subsurface testing to determine the extent of possibly intact cultural deposits.

\section{Historic Component}

Much of the historic component of $41 \mathrm{BX} 1257$ constructed by Colonel Coppock has been destroyed or at least heavily disturbed. The least disturbed elements are the stone and concrete tower and house foundation. These two elements should be avoided by planned construction. A design for the park presented by the project architect indicates these two elements are to be preserved and incorporated into the overall design. CAR concurs with such a plan. The design could be further enhanced by additional documentation of the structures and mapping of the locations of other structures and features constructed by the Colonel. Because of their unique design and architectural construction, the entire area encompassed by the previously mentioned structures is recommended as eligible for nomination to the National Register of Historic Places (NRHP).

\section{$41 B X 1258$}

41BX1258 appears to be minimally disturbed and, based on the presence of subsurface cultural material found in the two shovel tests, should be avoided by planned construction if possible. If the site cannot be avoided, we recommend further testing to determine the extent of possibly intact cultural deposits. 


\section{References Cited}

Abbe, D. R.

1996 Gray County. In The New Handbook of Texas, edited by R. Tyler, 2:296. The Texas Historical Commission. Austin.

Adkins, L., and R. A. Adkins

1982 A Thesaurus of British Archaeology. David and Charles, London.

Alexander, H. L.

1983 The Pre-Clovis and Clovis Occupations at the Levi Site. In Peopling of the New World, edited by J. E. Ericson, R. E. Taylor, and R. Berger, pp. 133-145. Ballena, Los Altos, California.

Barnes, V. E.

1983 Geologic Atlas of Texas: San Antonio Sheet. Bureau of Economic Geology. The University of Texas at Austin.

Bass F. A., Jr., and T. R. Hester

1975 An Archaeological Survey of the Upper Cibolo Creek Watershed, Central Texas. Archaeological Survey Report, No. 8. Center for Archaeological Research, The University of Texas at San Antonio.

Black, S. L.

1989a Central Texas Plateau Prairie. In From the Gulf Coast to the Rio Grande: Human Adaptation in the Central, South, and Lower Pecos Texas, edited by T. R. Hester, S. L. Black, D. G. Steele, B. W. Olive, A. A. Fox, K. J. Reinhard, and L. C. Bement, pp. 17-38. Research Series No. 33. Arkansas Archeological Survey, Fayetteville.

1989b Environmental Setting. In From the Gulf Coast to the Rio Grande: Human Adaptation in the Central, South, and Lower Pecos Texas, by edited T. R. Hester, S. L. Black, D. G. Steele, B. W. Olive, A. A. Fox, K. J. Reinhard, and L. C. Bement, pp. 5-16. Research Series No. 33. Arkansas Archeological Survey, Fayetteville.

1995 Archaeological and Historical Background. In Archaeological Investigations at the Loma Sandia Site (41LK28): A Prehistoric Campsite in Live Oak County, Texas. 2 volumes. Studies in Archeology No. 20, pp. 31-45. Texas Archeological Research Laboratory, The University of Texas at Austin.

Black, S. L., and A. J. McGraw

1985 The Panther Springs Creek Site: Cultural Change and Continuity in the Upper Salado Creek Drainage, South-Central Texas. Archaeological Survey Report, No. 100. Center for Archaeological Research, The University of Texas at San Antonio.

Black, S. L., L. W. Ellis, D. G. Creel, and G. T. Goode

1997 Hot Rock Cooking on the Greater Edwards Plateau: Four Burned Rock Midden Sites in West Central Texas (two volumes). Studies in Archeology 22. Texas Archeological Research Laboratory, The University of Texas at Austin. Texas Department of Transportation Environmental Affairs Department, Archeology Studies Program, Report 2. 
Bolton, H. E.

1915 Texas in the Middle Eighteenth Century: Studies in Spanish Colonial History and Administration. Volume 3, University of California Publications in History. University of California, Berkeley.

Brown, K. M.

1985 Three Caches of Guadalupe Tools from South Texas. Bulletin of the Texas Archeological Society 56:75-126.

Brune, G.

1975 Major and Historic Springs of Texas. Report \#189. Texas Water Development Board, Austin.

Campbell, T. N.

1975 The Payaya Indians of Southern Texas. Special Publications No. 1. Southern Texas Archaeological Association, San Antonio.

1983 Coahuiltecans and Their Neighbors. In Handbook of North American Indians Volume 10: Southwest, edited by A. Ortiz, pp. 343-358. Smithsonian Institution, Washington, D.C.

1991 Coahuiltecans and Their Neighbors. In Ethnology of the Texas Indians, edited by T. R. Hester. Spanish Borderlands Sourcebooks 7. Garland, New York.

Campbell, T. N., and T. J. Campbell

1985 Indian Groups Associated with Spanish Missions of the San Antonio Missions National Historical Park. Special Report, No. 16. Center for Archaeological Research, The University of Texas at San Antonio.

1981 Historic Indians of the Choke Canyon Reservoir Surrounding Area, Southern Texas. Choke Canyon Series, No. 1. Center for Archaeological Research, The University of Texas at San Antonio.

Chabot, F. C.

1937 With the Makers of San Antonio. Artes Graficas, San Antonio.

Chipman, D. E.

1992 Spanish Texas, 1519-1821. University of Texas Press, Austin.

Collins, M. B.

1995 Forty Years of Archaeology in Texas. Bulletin of the Texas Archeological Society 66:361-400.

Collins, M. B. and P. J. Headrick

1992 Comments on Kelly's Interpretations of the "Van Autry" Cores. La Tierra (19)4:26-39.

Creel, D. G.

1986 A Study of Prehistoric Burned Rock Middens in West Central Texas. Unpublished Ph.D. dissertation, The University of Arizona, Tucson.

Cutrer, T. W.

1996 Colquhoun, Ludovic. In The New Handbook of Texas, edited by R. Tyler, 2:231-232. The Texas Historical Commission. Austin. 
de la Teja, J. F.

1995 San Antonio de Bexár: A Community on New Spain's Northern Frontier. University of New Mexico Press, Albuquerque.

Dibble, D. S., and D. Lorrain

1968 Bonfire Shelter: A Stratified Bison Kill Site, Val Verde County, Texas. Miscellaneous Papers 1. Texas Memorial Museum, Austin.

Dillehay, $\mathrm{T}$.

1974 Late Quaternary Bison Population Changes on the Southern Plains. Plains Anthropologist 19(64): 180-196.

Ewers, J. C., editor

1969 The Indians of Texas in 1830. Publication Series 4745. Smithsonian Institution Press, Washington, D.C.

Fehrenbach, T. R.

1974 Comanches: The Destruction of a People. Alfred A. Knopf, New York.

1978 The San Antonio Story. Continental Heritage, Tulsa, Oklahoma.

1983 Lone Star: A History of Texas and the Texans. American Legacy, New York.

Flanagan, S.

1974 Trailing the Longhorns: A Century Later. Madrona, Austin.

Fox, A. A., and D. E. Fox

1967 The Classen Rockshelter, 41BX23. Manuscript on file. Center for Archaeological Research, The University of Texas at San Antonio.

Fox, A. A., I. W. Cox, L. Highley, and D. Hafernik

1989 Archaeological and Historical Investigations at the Site of the New Bexar County Justice Center in Downtown San Antonio, Texas. Archaeological Survey Report, No. 184. Center for Archaeological Research, The University of Texas at San Antonio.

Fox, D. F.

1982 Texas Department of Water Resources Cultural Resources Survey Form. Copy on file. Center for Archaeological Research, The University of Texas at San Antonio.

Fox, J., C. B. Smith, and D. O. Lintz

1992 Herd Bunching at the Waco Mammoth Site: Preliminary Investigations, 1978-1987. In Proboscidean and Paleoindian Interactions, edited by J. W. Fox, C. B. Smith, and K. T. Wilkins, pp. 51-73. Baylor University Press, Waco.

Freeman, M. D.

1994 Agriculture in Texas: Ranching and Stock Farming on the Eastern Edwards Plateau, 1845-1941. Komatsu/Rangel, Fort Worth. 
Gerstle, A., T. C. Kelley, and C. Assad

1978 The Fort Sam Houston Project: An Archaeological and Historical Assessment. Archaeological Survey Report, No. 40. Center for Archaeological Research, The University of Texas at San Antonio.

Givens, R. D.

1968 A Preliminary Report on Excavations at Hitzfelder Cave. Bulletin of the Texas Archeological Society 38:47-50.

Goode, G. T.

1989 Private Collections from the Kennedy Bluffs Site. In Excavations at 41BP19, the Kennedy Bluffs Site, Bastrop County, Texas, edited by L. C. Bement. Contract Report No. 5. Texas Department of Highways and Public Transportation, Austin.

1991 Late Prehistoric Burned Rock Middens in Central Texas, In The Burned Rock Middens of Texas: An Archaeological Symposium, edited by T. R. Hester, pp. 71-93. Studies in Archeology 13. Texas Archeological Research Laboratory, The University of Texas at Austin.

Habig, M.A.

1968a San Antonio's Mission San José, State and National Historic Site, 1720-1968. Naylor, San Antonio.

1968b The Alamo Chain of Missions, A History of San Antonio's Five Old Missions. Franciscan Herald, Chicago.

Hall, G. D., T. R. Hester, and S. L. Black (editors)

1986 The Prehistoric Sites at Choke Canyon Reservoir, Southern Texas: Results of the Phase II Archaeological Investigations. Choke Canyon Series, No. 10. Center for Archaeological Research, The University of Texas at San Antonio.

Hard, R. J., A. A. Fox, I. W. Cox, K. J. Gross, B. A. Meissner, G. I. Méndez, C. L. Tennis, and J. E. Zapata 1995 Excavations at Mission San José y San Miguel de Aguayo, San Antonio, Texas. Archaeological Survey Report, No. 218. Center for Archaeological Research, The University of Texas at San Antonio.

Harris, E. S.

1985 An Archaeological Study of the Timmeron Rockshelter (41HY95), Hays County, South Central Texas. Special Publication 4. Southern Texas Archaeological Association, San Antonio.

Henson, M. S.

1996 Harris County. In The New Handbook of Texas, edited by R. Tyler, 3:480-483. The Texas Historical Commission. Austin.

Hester, T. R.

1980 Digging into South Texas Prehistory: A Guide for Amateur Archaeologists. Corona, San Antonio.

1983 Late Paleo-Indian Occupations at Baker Cave, Southwestern Texas. Bulletin of the Texas Archeological Society 53:101-119.

1989 Historic Native American Populations. In From the Gulf to the Rio Grande: Human Adaptation in Central, South, and Lower Pecos Texas, edited by T. R. Hester, S. L. Black, D. G. Steele, B. W. Olive, A. A. Fox, K. J. Reinhard, and L. C. Bement, pp. 77-84. Research Series No. 33. Arkansas Archaeological Survey, Fayetteville.

1995 The Prehistory of South Texas. Bulletin of the Texas Archeological Society 66:427-459. 
Highley, L.

1984 Guadalupe Tools from Zavala County. La Tierra 11(1):28-35.

Highley, L., C. Graves, C. Land, and G. Judson

1978 Archeological Investigations at Scorpion Cave (41ME7) Medina County, Texas. Bulletin of the Texas Archeological Society 49: 139-194.

Houk, B. A., and J. C. Lohse

1993 Archaeological Investigations at the Mingo Site, Bandera County, Texas. Bulletin of the Texas Archeological Society 61:193-247.

Huebner, J. A.

1991 Late Prehistoric Bison Populations in Central and Southern Texas. Plains Anthropologist 36(137): 343-358.

Inglis, J. M.

1964 A History of Vegetation on the Rio Grande Plain. Bulletin \#45. Texas Parks and Wildlife Department, Austin.

Jackson, J.

1986 Los Mesteños: Spanish Ranching in Texas, 1721-1821. Texas A\&M University Press, College Station.

Jaquier, J. A.

1976 An Archaeological Survey for the Cibolo Creek Municipal Authority, South Central Texas. Archaeological Survey Report, No. 29. Center for Archaeological Research, The University of Texas at San Antonio.

John, E. A. H.

1975 Storms Brewed in Other Men's Worlds: Confrontations of Indians, Spanish and French in the Southwest, 1540-1795. Texas A\&M University Press, College Station.

Jones, W. K.

1969 Notes on the History and Material Culture of the Tonkawa Indians. Smithsonian Contributions to Anthropology 2(5). Smithsonian Institution, Washington, D.C.

Johnson, L. , Jr.

1967 Toward a Statistical Overview of the Archaic Cultures of Central and Southwestern Texas. Bulletin 12. Texas Memorial Museum, Austin.

1994 The Reconstructed Crow Terminology of the Titkanwatits, or Tonkawas, with Inferred Social Correlates. Plains Anthropologist (39) 150:377-413.

1995 Past Cultures and Climates at Jonas Terrace, 41ME29, Medina County, Texas. Office of the State Archeologist Report 40. Texas Department of Transportation and Texas Historical Commission, Austin.

Johnson, L., and G. T. Goode

1994 A New Try at Dating and Characterizing Holocene Climates, as well as Archaeological Periods, on the Eastern Edwards Plateau. Bulletin of the Texas Archeological Society 65:1-51. 
Johnson, L., and T. N. Campbell

1992 Sanan: Traces of a Previously Unknown Aboriginal Language in Colonial Coahuila and Texas. Plains Anthropologist 37(140):185-212.

Katz, P. R. (editor)

1987 Archaeological Mitigation at 4IBX300, Salado Creek Watershed, South-Central Texas. Archaeological Survey Report, No. 130. Center for Archaeological Research, The University of Texas at San Antonio.

Kelley, D.

1971 Indian Tribes of Texas, edited by D. H. Winfrey. Texian, Waco.

Kelly, T. C.

1992 Two Polyhedral Cores from Comanche Hill, San Antonio, Texas. In La Tierra 19(2):29-33).

Kelly, T. C., and T. R. Hester

1976 Archaeological Investigations at Sites in the Upper Cibolo Creek Watershed, Central Texas. Archaeological Survey Report, No. 15. Center for Archaeological Research, The University of Texas at San Antonio.

Krieger, A. D.

1964 Early Man in the New World. Prehistoric Man in the New World, edited by J. D. Jennings and E. Norbeck, pp. 23-81. University of Chicago Press, Chicago.

Leach, J. D., and C. B. Bousman

1998 Cultural and Secondary Formation Processes: On the Dynamic Accumulations of Burned Rock Middens. In Test Excavations at the Culebra Creek Site, 41BX126, Bexar County, Texas, edited by D. L. Nickels and C. B. Bousman, pp. 119-145. Archaeological Survey Report, No. 265. Center for Archaeological Research, University of Texas at San Antonio. In press.

Lehmann, V. W.

1969 Forgotten Legions. Texas Western, The University of Texas at El Paso.

León, A., J. B. Chapa, and F. S. de Zamora

1961 Historia de Luevo León, con Noticias sobre Coahuila, Tamaulipas, Texas y Nueva México. Estudio Preliminar y Notas de Israel Cavzos Garza. Centrio de Estudios Humanistico. Universidad de Nuevo León, Monterrey.

McGraw, A. J.

1977 A Preliminary Archaeological Survey Along The Medio Creek Drainage, Southwestern Bexar County, Texas. Regional Studies, No. 3. Center for Archaeological Research, The University of Texas at San Antonio.

McGraw, A. J. and F. Valdez Jr.

1978 41BX68: A Prehistoric Quarry-Workshop in Northern Bexar County, Texas. Archaeological Survey Report, No. 56. Center for Archaeological Research, The University of Texas at San Antonio 
McGraw, A. J., and K. Hindes

1987 Chipped Stone and Adobe: A Cultural Resources Assessment of the Proposed Applewhite Reservoir, Bexar County, Texas. Archaeological Survey Report, No. 163. Center for Archaeological Research, The University of Texas at San Antonio.

McGraw, A. J., F. Valdez, Jr., and I. W. Cox

1977 Archaeological Survey of Areas Proposed for Modification in the Encino Park Development, Northern Bexar County, Texas. Archaeological Survey Report, No. 39. Center for Archaeological Research, The University of Texas at San Antonio.

Mc Graw, A. J., J. W. Clark, and E. A. Robbins (editors)

1991 A Texas Legacy, the Old San Antonio Road and the Caminos Reales: A Tricentennial History, 16911991. Texas State Department of Highways and Public Transportation, Highway Design Division. Austin.

McKinney, W. W.

1981 Early Holocene Adaptations in Central and Southern Texas: The Problem of the Paleo-Indian- Archaic Transition. Bulletin of the Texas Archeological Society 52:91-120.

Meltzer, D. J., and M. R. Bever

1995 Paleoindians of Texas: An Update on the Texas Clovis Fluted Point Survey. Bulletin of the Texas Archeological Society 66:47-81

Mueggenborg, H. E.

1994 Excavations at the Blue Hole Site, Uvalde County, Texas, 1990. Bulletin of the Texas Archeological Society 62:1-74.

Newcomb, W. W., Jr.

1961 The Indians of Texas: From Prehistoric to Modern Times. University of Texas Press, Austin.

Nickels, D. L.

1998 An Archaeological and Geomorphological Investigation of 103-acre Northrup Park, Boerne, Kendall County, Texas. Archaeological Survey Report, No. 247. Center for Archaeological Research, The University of Texas at San Antonio.

Nickels, D. L., D. W. Pease, and C. B. Bousman

1998 Archaeological Survey of Lackland Air Force Base, Bexar County, Texas. Archaeological Survey Report, No. 248. Center for Archaeological Research, The University of Texas at San Antonio.

Patterson, L. W.

1988 Intergroup Conflict in Prehistoric Texas. Houston Archeological Society Journal 90:8-10.

Peter, D. E.

1982 Alternative Perspectives on Burned Rock Middens, In Archaeological Investigations at the San Gabriel Reservoir Districts, Central Texas, Vol. 2, compiled and edited by T. R. Hays, pp. 20.1-20.15. Archaeology Program, Institute of Applied Sciences, North Texas State University, Denton. 
Potter, D. R., S. L. Black, and K. Jolly

1995 Archeology Along the Wurzbach Parkway. Module 1. Introduction, Conceptual Framework, and Contexts of Archeological Investigations in Bexar County, South-Central Texas. Studies in Archeology 17. Texas Archeological Research Laboratory, The University of Texas at Austin.

Poyo, G. E., and G. M. Hinojosa (editors)

1991 Tejano Origins in Eighteenth-Century San Antonio. University of Texas Press, Austin.

Prewitt, E. R.

1981 Culture Chronology in Central Texas. Bulletin of the Texas Archeological Society 52:65-89.

1985 From Circleville to Toyah: Comments on Central Texas Chronology. Bulletin of the Texas Archeological Society 54:201-238.

San Antonio Express Magazine (SAEM)

1948 Comanche Lookout. 11 January.

San Antonio Express-News (SAEN)

1993 For Some, RTC was Samaritan. 24 January.

1994 Council to Buy Land for New Park. 3 June.

1997 'Natural' Comanche Lookout Urged. 7 May.

San Antonio News

1972 Historical Places. 14 November.

Simpson, B. J.

1988 A Field Guide to Texas Trees. Gulf, Houston.

Sjoberg, A. F.

1953a The Culture of the Tonkawa, A Texas Indian Tribe. Texas Journal of Science 5(3):280-304.

1953b Lipan Apache Culture in Historical Perspective. Southwestern Journal of Anthropology 9(1):76-98.

Skelton, D. W.

1977 Archeological Investigations at the Fayette Power Project, Fayette County, Texas. Research Report 60. Texas Archeological Survey, The University of Texas at Austin.

Sollberger, J. B., and T. R. Hester

1972 The Strohacker Site: A Review of Pre-Archaic Manifestations in Texas. Plains Anthropologist 17(58):326-344.

Sollberger, J. B., and W. B. Carroll

1985 Guadalupe Tools: Were They Used for Defleshing Hides? La Tierra 12(1):18-22.

Steele, D. G., and C. Assad Hunter

1986 Analysis of Vertebrate Faunal Remains from 41MC222 and 41MC296, McMullen County, Texas. In The Prehistoric Sites at Choke Canyon Reservoir, Southern Texas: Results of Phase II Archaeological Investigations, edited by G. D. Hall, T. R. Hester, and S. L. Black. Choke Canyon Series, No. 10. Center for Archaeological Research, The University of Texas at San Antonio. 
Story, D. A.

1985 Adaptive Strategies of Archaic Cultures of the West Gulf Coastal Plain. In Prehistoric Food Production in North America, edited by R. I. Ford, pp. 19-56. Anthropological Papers No. 75. Museum of Anthropology, University of Michigan, Ann Arbor.

Strong, B.

1996 James, John. In The New Handbook of Texas, edited by R. Tyler, 3:905-906. The Texas Historical Commission, Austin.

Suhm, D. A., A. D. Krieger, and E. B. Jelks

1954 An Introductory Handbook of Texas Archeology. Bulletin of the Texas Archeological Society 25.

Swanton, J. R.

1952 The Indian Tribes of North America. Bulletin 145. Bureau of American Ethnology, Washington, D.C.

Taylor, F. B., R. B. Hailey, and D. L. Richmond

1991 Soil Survey of Bexar County, Texas. Soil Conservation Service, U.S. Department of Agriculture, Washington, D.C.

Turner, E. S., and T. R. Hester

1993 A Field Guide to Stone Artifacts of Texas Indians. Second Edition. Texas Monthly Field Guide Series. Gulf, Houston.

Weir, F. A.

1976 The Central Texas Archaic. Unpublished Ph.D. dissertation. Anthropology Department, Washington State University. Pullman.

West, E. H. (translator)

1904 A Brief Compendium of the Events Which Have Occurred in the Province of Texas from its Conquest, or Reduction to the Present Day, Written by Antonio Bonilla in 1772. Quarterly of the Texas State Historical Association VIII(1):1-78.

Wilbarger, J. W.

1985 Indian Depredations in Texas: Original Narratives of Texas History and Adventure, 1885. Reprinted by Eakin, Austin. 


\section{Appendix A. Artifact Data}

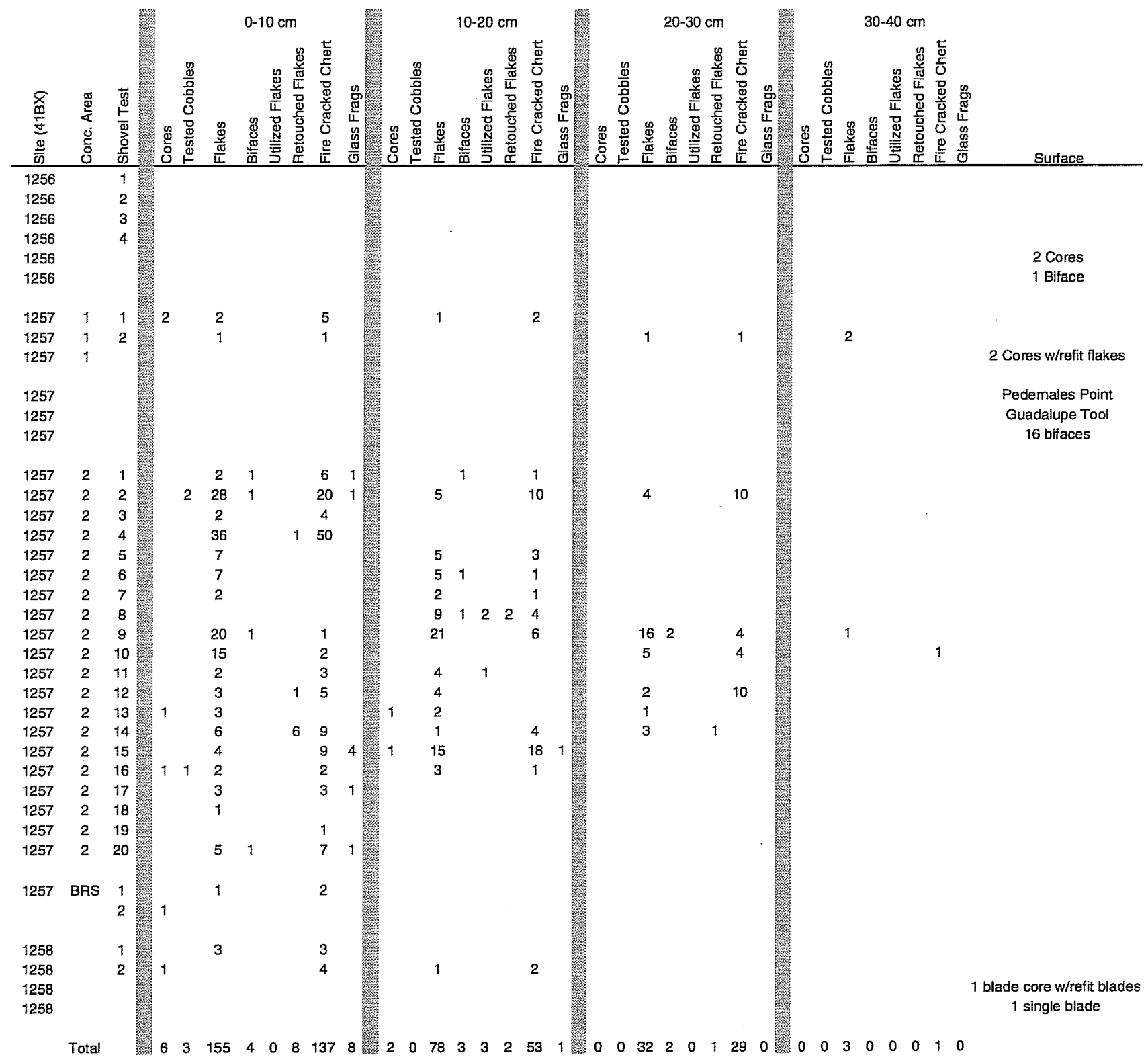

Note: All shovel tests were dug to either $50 \mathrm{~cm}$ below surface or to bedrock; no cultural material was recovered below $40 \mathrm{~cm}$

BRS = the bumed rock scatter identified by Smith et al. 1992 and tested by CAR during the current project. 
